\title{
A Study Of
}

Some Factors Influencing Fruitfulness in Apples

ClEO CLAUdE WIGGANS, B.S. Agr., A.M.

SUBMITTED IN PARTIAL FULFILMENT OF THE REQUIREMENT FOR THE DEGREE OF DOCTOR OF PHILOSOPHY

UNIVERSITY OF MISSOURI

COLUMBIA 



\section{A Study Of \\ Some Factors Influencing Fruitfulness in Apples}

ClEO CI.AUDE WIGGANS, B.S. Agr., A.M.

SUBMITTED IN PARTIAL FULFILMENT OF THE REQUIREMENT FOR THE DEGREE OF DOCTOR OF PHILOSOPHY

UNIVERSITY OF MISSOURI

COLUMBIA 


\title{
UNIVERSITY OF MISSOURI \\ COLLEGE OF AGRICULTURE $5 B^{36^{2}}$ Agricultural Experiment Station
}

\author{
BOARD OF CONTROL \\ THE CURATORS OF THE UNIVERSITY OF MISSOURI \\ EXECUTIVE BOARD OF THE UNIVERSITY \\ SAMI SPARROIV, Chairman, \\ Kansas City \\ C. B. ROLLINS, \\ Columbia
}

JOHN H. BRADLEY,

Kennett

ADVISORY COUNCIL

THE MISSOURI STATE BOARD OF AGRICULTURE

\author{
OFFICERS OF THE STATION \\ A. ROSS HILL, PH. D., LL. D., PRESIDENT OF THE UNIVERSITY \\ F. B. MUMFORD, M. S., DIRECTOR
}

\section{STATION STAFF}

AGRICULTURAL CHEMISTRY

C. R. Moulton, Ph. D.

L. D. Halgh, Ph. D.

L. S. PALMER, Ph. D.

S. B. SHIRKEY, B. S. in Agr.

C. E. MIANGEls, 1 M. S.

T. H. HOPPER, $\mathrm{M}$. S.

V. F. PAYNe, A. B.

Mrs. Mary Cochrane Farris, B. S. in Agt. AGRICULTURAL ENGINEERING

E. H. LeHAANN, B. S. in A. E. ANIMAL HUSBANDRY

E. A. Trowbridge, B. S. A.

F. B. MUMFORD, M. S.

H. O. Allison, M. S.

L. A. WEAVER, B. S. in Agr.

D. J. Griswold, A. M. BOTANY

George M. Reed, Ph. D.

Helen JOIIAN , A. M.

\section{DAIRY HUSBANDRY}

C. H. EckLes, MI. S., D. Sc.

iV. B. Com Bs, A. II.

IV. IV. SWETT, A. M.

II. H. Folrman, B. S. in Agr.

P'ERCY IVIRNER, JR, ${ }^{1}$ A. M. ENTOMOLOGY

LFonard Haseman, $\mathrm{Ph}$. D.

K. C. Sullivan, A. M. FARM CROPS

IV. C. Ethinidge, Ph. D.

E. M. MCDONald, B. S.

C. A. HELM, A. M.

J. B. SMITH, A. M.

I. J. Stadler, A. M.

\section{FARM MANAGEMENT}

O. R. JOHNSON, 1 A. M.

R. M. GreeN, B. S. in Agr. FORESTRY

FrEderick DuNLAP, F. E.

E. C. PEgG, M. F. HORTICULTURE

V. R. Gardner, M. S. A.

II. F. MaJOR, B. S. A.

J. T. Rosa, JR., M. S. H

H. G. Swartwout, B. S. in Agr. POULTRY HUSBANDRY

H. L. KeMPSTER, B. S.

G. IV. HERVEY, B. S. SOILS

M. F. Milleer, M. S. A.

R. R. HUdLESON, ${ }^{1}$ A. M.

IV. A. Albrecht, M. S.

F. L. Duley, A. M

H. H. KRUSEKOPF, A. M.

Wir. DEYOUnG, B. S. in Agr. VETERINARY SCIENCE

J. W. Connoway, D. V. M., M. D.

L. S. Backus, D. V. M.

O. S. Crisler, D. V. M.

A. J. Durant, A. M.

H. G. NEWMAN, B. S. in Agr.
OTHER OFFICERS

- \{ R. B. PrICE, M. S., Treasurer

J. G. BABB, A. M., Secretary

E. H. Hughes, A. M., Asst. to Dean O. IV. WEaver, B. S., Agricultural Editor GEORGE REEDER, Director Weather Bureau Rachel Holmes, ${ }^{2}$ A. B., Seed Testing Lab. oratory

J. F. BARHAM, Photographer

${ }^{1}$ In U. S. Military Service.

'In service of U. S. Department of Agriculture.

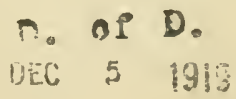




\section{SOME FACTORS FAVORING OR OPPOSING FRUITFULNESS IN APPLES *}

\section{The Effect of Certain Conditions and Practices on the Development and Performance of the Individual Fruit Spur}

\section{C. WIgGans}

\section{INTRODUCTION}

It is a generally observed fact that certain varieties of apples tend to bear crops in alternate years, while others produce annual yields. Some varieties are light bearers but others yield heavy crops. In some cases the same variety, or even the same tree, shows great variation in its performance from year to year. The principles underlying these variations in behavior are of scientific interest as well as of great importance to practical fruit growers. Horticultural literature contains numerous references to the biennial crops of the Baldwin in the New England and New York fruit growing sections. Among the varieties grown in Missouri, the Ben Davis, Gano, Ingram, and York show marked alternation of crops, while the Jonathan, Winesap, Grimes, and Missouri generally may be depended upon to give satisfactory crops each year.

The investigator in considering the factors influencing fruitfulness in apples, must, first of all, give his attention to a study of the principles underlying fruit bud formation, for the flower must, of course, precede the fruit. Many and varied have been the opinions of investigators as to the factors causing flower production. The argument has sometimes been advanced that the blooming power is inherited, while some writers have maintained the view that flowers are dependent upon the presence of a certain specific "blossom building" substance. The latter view has been especially noticeable among German investigators. Environmental factors such as light, heat, accident, etc., have been considered the all important ones in some cases, while in others, the effects of certain cultural practices have been used as a basis for the explanation of the phenomenon. Seemingly, the problem has been of as much interest to plant physiologists and morphologists, as to the practical growers themselves.

*Also presented to the Graduate School of the University of Missouri, June, 1918. as a thesis in partial fulfillment of the requirements for the degree of Doctor of Philosophy.

ACKNOWLEDGMENT. The writer wishes to acknowledge bis indebtedness to the following named men who assisted him to plan and carry out this investigation: Dr. J. C. Whitten, Dr. G. M. Reed, Dr. P. F. Trowbridge, and Mr. H. G. Swartwout. 
It has long been recognized by those interested in plant life that in every plant there are two seemingly antagonistic forces, one of which is striving to preserve the individual plant, and the other, to perpetuate the species. The first of these activities expresses itself in the formation of purely vegetative parts, such as stems, roots and leaves, thru which the life of the individual may be lengthened, while the latter has to do with the formation and maturation of seeds in greater or smaller numbers by which the species may be carried over from one generation to the next. The former may be spoken of as vegetative activity and the latter as reproductive activity, or, in the case of fruit trees, as wood growth and fruit growth.

Vegetative activity always precedes reproductive development and, so long as it proceeds with undiminished vigor, few or no blossoms will be formed. With our tree fruits the period of vegetative activity may be several years in length while with certain annual plants it may be a matter of only a few weeks. In any case, however, the maximum vegetative period passes before heavy reproduction begins. Maintaining the vigor of the wood growth serves very materially to dclay the formation of fruits, while, on the other hand, a heavy fruit crop tends to decrease greatly the vegetative growth. From these general observations, the obvious conclusion has been reached that it is impossible to have the greatest efficiency in both wood and fruit growth simultaneously in a single individual. A plant, then, cannot be of the highest degree of service to itself and to its species at one and the same time.

Apple trees during the first few years of their life produce few or no blossoms. The energies of the plant are directed to the formation of a framework of branches upon which the later crops of fruit are to be borne. Finally, however, the bearing age is reached but this is found to differ very materially in the different varieties and even in the same variety when grown under different cultural and soil conditions. From this time until its death, the tree remains a potential fruit bearing organization. The amount of fruit borne, however, often shows a very striking variation, ranging from a very light crop to a very heavy one. This phenomenon is sometimes spoken of as alternation.

Alternation, referring primarily to the bearing of heavy and light crops in alternate seasons, seems to be more or less a varietal characteristic. With certain varieties regular crops are expected, while with others a heavy crop is almost invariably followed by a light one. This habit of alternation also seems to be much more 
characteristic of our later commercial varieties than of some of the older sorts grown in the orchards of the early settlers. This may have come about because of the emphasis that is now placed upon high yields. In the earlier days, when markets were limited, regular crops were more desirable than heavy crops.

In an investigation of the factors influencing fruitfulness in apples, so many avenues of research are open that it is folly to attempt to take all of them into consideration in a single investigation which must be more or less limited to certain lines. Previously, nearly all investigators have been inclined to consider the problem from the standpoint of the entire tree, or, of the entire orchard, in its relation to a specific treatment or factor. In this study, however, the main idea centers around the factors and conditions influencing the behavior of an individual fruit spur. Since the tree is composed of numerous individual fruiting parts, the factors influencing the individual spur must ultimately have a proportionate influence upon the entire organization. Hence an attempt has been made to keep constantly in mind the fruiting parts as individuals rather than in mass, and the greater part of the work has been done with the individual fruit spurs.

Moreover, for the purpose of this study, it is gcnerally assumed that a blossoming spur is also a fruiting spur. Under field conditions, however, some flower clusters may fail to set fruit, but the fact still remains that a spur developing a blossom is a potential fruiting spur for the following year, and it is here so considered.

\section{LITERATURE}

A critical review of the literature bearing upon the factors favoring or opposing fruitfulness in apples reveals the fact that many explanations have been offered for the variations found in the fruiting habit of an apple tree. It is quite noticeable that many of these explanations are based upon general observations and conclusions rather than upon actual scientific data, and especially is this true in the older writings. Definitely planned experimental work is virtually confined to the last twenty-five years, and dates approximately from the time the agricultural experiment stations became well established in research work.

Not all writers have been interested directly in the production of an increased number of blossoms for some have been concerned with the reserve materials which are always found to be present in woody plants. The amount and nature of these reserves vary accord- 
ing to the season and character of the part under consideration, and these variations have sometimes been used as a basis to explain the phenomena observed. Thus, are recorded not only the observations of horticulturists but those of biologists and chemists as well.

The natural evolutionary development of the apple during the centuries that it has been under cultivation, has very likely had considerable influence upon the cultural practices of the succeeding periods. Therefore, it seems but natural to suppose that the management suitable for the apple as it was first known would be not at all applicable to the modern commercial high yielding varieties. Also, an increasing knowledge of plant structure and function, in all probability, has been productive of improved methods of fruit growing. All recommendations, however, based upon either general observations or actual knowledge, have for their purpose an increase in the yield or an improvement in the character of the fruits borne.

One point upon which the majority of writers are in perfect accord is, that fruit bud formation is dependent upon a supply of reserve food material. With the better understanding of the sap flow in plants, this idea has become more and more prominent. Even the early writers seemed to appreciate that there is some connection between the food supply and the sap, and hence they devised methods by which they thought they could modify the sap and thereby also influence the food supply. Particular methods were evolved for the various parts of the plant and changes in the character of the food supply, etc., were also suggested.

Since many of the writers have considered the effects of several methods or treatments upon fruitfulness, it seemed advisable to consider the literature in chronological order rather than by topics. This plan has been used in the following review:

One of the earliest records found of an interest being taken in the factors influencing fruitfulness is the statement of Lonicerus (1587) quoted by Zacharias ${ }^{152 *}$. This early writer seems to have reached the conclusion that an excess of nourishment leads to a very marked extension of the vegetative branches, but that no fruit will be borne under these conditions. This same doctrine, that great vegetative growth is not compatible with great reproductive activity, can be subscribed to today.

According to Noehden ${ }^{104}$, Van Oosten, (1711) the Dutch botanist, stated that a "moderate sap flow," secured by frequent transplanting or by summer pruning, will result in fruit production. While

* See bibliography for this and subsequent number references thruout. 
he probably possessed very little knowledge concerning the sap flow, yet this writer suggested two methods which will encourage fruitfulness and these methods are even now sometimes used for this purpose.

The beneficial effects of ringing were observed by De la Baisse (1753), Bonnet (1754) and Duhamel (1758). These reports were recorded by Mobius $^{99}$. Duhamel apparently seems also to have had some knowledge of the effects of pruning.

Knight ${ }^{78}$ early in the nineteenth century published many papers dealing with horticultural subjects. Among his observations, Knight made note of the increased fruitfulness of horizontal branches as compared with upright ones. He explained this by the assumption that the decreased sap movement in the horizontal branches was the direct cause of their greater fruitfulness. He suspected that the heavy fruit crops borne immediately following a warm bright season when only a few fruits were matured, was due to the fact that the sap had not been expended in maturing an excessive crop. In some of his earlier papers he leaned to the belief that the bearing age of a tree is dependent to a large extent upon hereditary factors, but later, ringing is mentioned as a way of increasing fruitfulness, this being due to the accumulation of descending sap. Knight really had a much better knowledge of plant physiology than his predecessors and hence was enabled to give a more nearly correct interpretation of his results. It is interesting to note the close agreement between some of his ideas and those of the present day.

Forsyth $^{46}$ in a textbook on the general subject of fruit growing published in 1802 made the following statement, "Never shorten the young branches except they are very thin......nor prune any of the young shoots the second year, as many of the eyes, almost at the end of the shoot, will, if it be strong, become fruit buds next year." Evidently, this writer had been making some very accurate observations upon the method of fruit spur formation.

That fruit bud formation may be stimulated by checking or diminishing the growth was the opinion of Noehden ${ }^{104}$ (1818). Ringing was suggested as one means of accomplishing this end.

Prince $^{118}$ (1830) believed that the amount of available moisture had a marked effect upon the fruitfulness of grapes.

Philips"12 (1831) declared that, "Pruning is to be avoided as much as possible as it creates useless branches and prevents the fruiting." Cole ${ }^{28}$ (1849) mentioned the following factors as being conducive to fruitfulness and early bearing; root pruning, ringing, 
bending down the branches, transplanting, use of certain stocks, shortening-in, and change of soil or climate. He stated also that certain varieties are regular bearers while others bear only in alternate years. However, he did not agree with the opinions expressed by others that this alternation is due to exhaustion and points out, in support of his contention, that certain kinds produce annual crops. In his opinion, the bearing year in alternating varieties may be changed by removing all of the blossoms during the heavy bearing year.

Barry $^{13}$ (1851), after observing that fruit buds originate as leaf buds, the differentiation taking place during the latter part of the growing season, finally stated that the immediate causes of fruit bud formation are not satisfactorily understood. He quoted Dubreuil, however, as being of the opinion that fruit buds are dependent upon stored plant food and that their formation is brought about if the circulation of sap is obstructed. This obstruction causes a slowing up of the sap movement so that the sap is more thoroly elaborated, and hence, becomes better adapted to fruit bud formation. Lindley ${ }^{83}$ (1852) believed that plants must attain a certain age before flowers will be formed, and that this age may be influenced materially by the nutrition of the tree. He further stated that fruit bud formation is probably due to an accumulation of plant food.

Field $^{41}$ (1859) recommended breaking, pinching, and twisting the branches as methods of inducing fruitfulness in the pear. $\mathrm{He}$ believed also that a large quantity of fibrous roots is essential for fruit production and hence root pruning may be practiced. Downing $^{36}$ (1864) agreed with Field that root pruning may be useful but he assigned an entirely different reason for it. By lessening the root system an overabundance of plant food is made available for the branches and this material then forms fruit buds. In the opinion of this writer, heavy crops exhaust the tree and thus cause alternation. However, this habit may be overcome by thinning while the apples are small. He also recommended that the soil be kept in "high condition."

Rivers $^{121}$ (1866) was a very strong advocate of root pruning, especially for dwarf trees, as a remedy for barrenness. He supposed that trees could be kept fruitful only by preventing the formation of large roots since these go downward and imbibe crude sap which causes great twig growth and few or no fruits.

Warder $^{143}$ (1867) summed up his observations by stating that fruit bud formation is due to the accumulation within the tree of nutritive materials, and the exhaustion of the soil of wood-forming 
elements. From the time the tree reaches maturity, then, the bearing habit is regulated by the balance between the materials which produce wood and those that produce fruit. Young trees need summer pruning to check their vigor and cause laterals to develop while older trees requirc dormant pruning to thin the fruit and to renew the vigor. Thus, it is seen that in the young trees, vegetative vigor must be restrained and fruit production encouraged, while in the aged trees, the exact opposite is the case.

For twenty-five years following the publication of Warder's "American Pomology" very few papers appeared dealing with the fruitfulness of apples. Seemingly, the writers of this period were content to let the question stand without additional comment. However, about 1880 there began to appear frequent articles concerning the chemical nature of the stored plant reserves. Halsted ${ }^{61}$ (1890) pointed out the importance of reserves to trees and also made some descriptions of the various storage tissues. He found but little apparent difference between leaf buds and fruit buds so far as sugar storage was concerned. However, he pointed out that leaf buds store up much more starch than the others on account of the fruit buds having to supply the developing fruit with this material. In his opinion flower buds are not terminal but rather simply overshadow the terminal leaf bud which is down among the blossoms. Fischer ${ }^{43}$ (1891) also called attention to the importance of reserves, and of their activities before any exterior growth takes place.

Maynard $^{97}$ (1888) concluded from some girdling experiments with crabapple trees that girdling will cause the production of an abnormal number of blossom buds but that it is an unsafe stimulus to use. Taft ${ }^{135}$ (1891) gave root pruning as one cause of fruitfulness, but stated that this practice is not to be recommended. Quinn ${ }^{119}$ (1832) said that summer pruning causes a change in the flow of sap from the ends of the branches which results in fruit formation. Gurney ${ }^{60}$ (1894) assigned exhaustion as a cause of alternation but said, "Bearing only in alternate years can in a large measure be broken up by a careful system of feeding or fertilizing."

Soraner ${ }^{130}$ (1895) has given this problem considerable attention, mainly from the physiological point of view. He maintained that under certain conditions, controllable to some extent by man, buds may be changed from one form to another. He said in part:

"Plants will only develop flowering buds when the food material formed in the leaves is copiously stored up in the stem and branches as reserve material, and not when this material is immediately used up in the production of new vegetative organs. 
"Of our apple trees it is a well known fact that in warm insular climates they grow into magnificent foliage trees but remain unproductive of fruit.

"That a diminution of the supply of water accompanies the production of flowers in nature may be gathered from the fact that most trees and shrubs produce their flowers on short reduced branches or spurs. The comparison of the anatomical structure of such a short shoot with that of a long leafy shoot confirms our statement, too, that an increase in stored food material is necessary for the production of flowers. The former shoots have by far more storage tissue than the latter........

"The withholding of water in such a treatment prevents the use of assimilated plant substance for the growth of new shoots and causes it to be stored up near the buds.

"For the production of flowering buds it is essential to decrease the supply of water and of nitrogenous salts, to increase the phosphates supplied to the plants and to increase the illumination."

Sorauer also discussed to some extent the effects of pruning upon fruitfulness and suggested that bending, twisting, notching, ringing, and peeling may be used to make pruning even more effective.

Klebs $^{76}$ (is90-1905) published several papers upon subjects relating to the reproduction of plants. His earlier investigations were carried out with algae and fungi because of their simplicity and rapidity of development, and also because the external conditions could be so easily and at the same time absolutely controlled. From the lower forms, however, he progressed to the use of the higher species and his later experiments were with phanerogams. This writer, in particular, emphasized the fact that the environment of a plant plays a most important role in the rate and kind of development made by it and its various parts. He showed that a plant may remain vegetative indefinitely if placed under the proper conditions. On the other hand, when the vegetative growth is inhibited reproduction at once begins. These changes in the character of the growth may be brought about entirely by a change in external conditions.

Work with the lower plants convinced Klebs that reproduction is affected by the amount and intensity of light, heat, moisture, and food supply, while the later experiments led him to believe that higher plants reacted in precisely the same way. Plants pass from the vegetative to the flowering state with changes in their external conditions and, at the same time, interior changes resulting in greater storage of plant food may also be taking place. Flowers, however, are not the result of an absolute amount of nourishment but rather of the relation between the decomposition and recomposition of these substances. In support of this opinion, he pointed out the fact that 
badly nourished plants always blossom early. Intense light and low humidity are favorable to flower production and the intensity of nutrition also has great significance in this connection. Lessening the food supply results in flower production, provided the plant possesses reserves. This is the condition brought about by ringing. Whether external conditions are to exert a favorable or unfavorable influence upon reproduction depends altogether upon the effect which they have upon internal conditions.

Other investigators coming after Klebs and Sorauer have submitted additional proof that there is a definite relation between the food supply and the character of plant development. External conditions favoring flower growth always oppose extensive twig and leaf development. External conditions favoring great availability of plant food always result in vigorous vegetative growth. Climatic conditions may have quite an influence in this respect. This was very forcibly brought out by Balmer ${ }^{10}$ (1896) in describing the difference in the fruiting labits of the same variety when planted under different conditions. In a region where rainfall is abundant, excessive vegetative growth is noticed, while in a section where the rainfall is much less, even the young trees tend to overbear. This, of course, means that much more attention must be given to pruning and other orchard operations under those conditions.

During the more recent years a considerable literature has been developed in connection with the effects of such orchard operations as pruning, fertilization, cultivation, spraying, ringing, etc., and along with this, some general observations with regard to the fruiting habit.

Schweitzer ${ }^{127}$ (1898) commenting upon the results secured from the ash analysis of twigs from apple trees said, "surely the much larger absolute amount of lime, phosphoric acid and potash in the bearing twigs must be either the cause or the condition of their bearing."

Bailey $^{7}$ (1898) enumerated several factors that may cause barrenness in apple trees but finally stated that in the nature of the tree there is no reason why it should not fruit more or less continuously. Later ${ }^{8}$ (1911) this same author concluded that the side bud on a bearing spur does not receive sufficient nourishment to develop into a fruit bud and, even tho the blossoms may be removed, it still may not produce a fruit bud for the following year. Waldron ${ }^{142}$ (1899) mentioned an "inherited tendency" to produce flower shoots as being a very potent cause of fruitfulness.

Goff $\mathrm{f}^{52} 53$ (1899-1901) in making studies of blossom formation in our common tree fruits showed that environmental factors have 
great influence upon the early development of the bud. He concluded that fruit buds are due to nutrition rather than structure since a spur may bloom at one, two, or three years of age, or it may never bloom, and also because of the fact that a spur may bloom and even fruit two years in succession. Alternation is not due to exhaustion since a weakened or exhausted tree always produces a large number of blossoms. Very favorable conditions for fruit bud formation result in such great development of these buds during that season that no spurs remain for the development of buds for the succeeding crop. $\mathrm{He}^{55}$ also said (1916) "a water supply insufficient for rapid growth may suffice for abundant fruit bud formation," and then called attention to the fact that fruit buds are usually formed during the drier part of the year.

Daniel $^{32}$ (1900) declared that from the physiological standpoint there is little or no difference in the effects of girdling and grafting.

Experimental evidence submitted by Brown and Escomber (1902) indicates that the amount of carbon dioxide in the air has a very marked effect upon flower formation.

Thomas $^{137}$ (1902) called attention to the fact that some varieties fruit more abundantly on the younger wood than do other sorts. $\mathrm{He}$ also stated that summer pruning hastens the formation of fruit spurs near the base of the pruned twig much more than dormant pruning.

Speaking with reference to thinning, Peach ${ }^{16}$ (1903) said, "thinning the fruit does not appear to cause any material change in either the amount or regularity of the fruit production."

Sablon $^{123}$ (1903) reported that the reserves in the twigs of a pear grafted upon a quince root are greater than those of a tree growing upon its own roots, thus tending to make it more fruitful. Later $^{125}$ (1906) he made further studies upon the reserves of trees and found that the great variation in the kind and amount of these reserves was dependent upon the season and the part under consideration.

Loew $^{85}$ (1905) combated the idea of earlier German writers that there is a specific blossom building material when he stated that blossoms are the result of a certain concentration of sugars. Fischer ${ }^{44}$ (1905) agreed with Loew that there is no special blossom forming substance. He also stated that girdling, instead of causing starvation of the parts above the girdle, results in an accumulation of plant reserves thereby causing greater blossom production. 
Flowers and flower bud formation require a relatively high illumination according to Clark $^{27}$ (1905), a fact which is supported by Paddock's ${ }^{108}$ (1905) account of the greater and earlier fruitfulness of trees in the increased sunsinine of high altitudes.

Chandler $^{24}$ (1905) presented the idea that alternation is due more to the formation of the blossom than to the later development of the fruit and for this reason thinning is not effective in overcoming the alternating habit. He also stated that the bearing habit can be controlled by pruning only in case the pruning dates from the early development of the tree. Herrick ${ }^{67}$ (1910) reached the conclusion that systematic thinning should have some influence toward annual cropping, thercby doing away with the "off years" of certain varieties.

According to Ikeda ${ }^{71}$ (1910) the Japanese fruit growers have always felt that alternation is due to nature and can not be controlled in any way. He then told of the pruning which is done by breaking off the bearing twigs at the time the fruit is harvested.

Waugh $^{14 \pm}$ (1910) reached the conclusion that if a tree is starved, it will make no new growth, the spurs will deteriorate, and the crops become scant, while too much wood growth will take place at the expense of the spurs and fruit.

Manaresi and Tonegutti9395 (1910) found that fruit-bearing wood is much richer in nutrients than foliage-bearing parts, and also that there are material differences in the size and shape of the leaves on the bearing and non-bearing spurs.

Although Newell ${ }^{102}$ (1910) stated that a single bud naturally cannot produce two crops in succession, yet, according to this author, the tree can be kept bearing annually. He expressed the opinion that the fruit bud receives no sap until the needs of the end of the branch have been fully satisfied.

Stewart ${ }^{132}$ (1910) said, "the off year may be frequently largely overcome by fertilization and other care," and later ${ }^{133}$ (1917), recommended for maintaining high and uniform yields, first, the prevention of large crops by thinning, second, an ample supply of food and moisture, and third, the avoidance of injury to the roots thru cultivation, etc.

Pickett $^{113}$ (1911) reported that while fertilization had iittle or no effect upon the number of fruit buds, cultivation with or without a cover crop always showed an increase. A proper balance, easily destroyed by too much pruning, or other treatment, between the working area of the foliage and the food supply, is necessary to 
insure a full and regular supply of fruit buds in apple orchard ${ }^{114}$ (1913).

Paddock and Whipple ${ }^{110}$ (1911) observed that varieties which frequently form fruit buds upon the one year wood are more likely to be annual bearers than varieties which fruit only on the older parts. The alternation of individual spurs is, in their estimation, due to a depletion of their energies by the fruit during the bearing year.

Dry weather at the time of fruit bud formation always makes a good prospect for the next year's crop, according to Macoun ${ }^{88}$ (1912).

Batchelor $^{14}$ (1913) thought that the spur needs a year to recover its exhausted energies after fruiting, and hence, a light crop is borne in alternate years. Newsham ${ }^{103}$ (1913) agreed with this statement and then added that removing the blossoms or young fruit tends to cause annual crops. This writer also stated that checking the growth, while inducing fruitfulness, does not maintain it.

Magnien $^{92}$ (1913) recommended basic slag as a fertilizer for apples because it leads to abundant fruit bud production. According to Remy ${ }^{120}$ (1913), blossom formation is not affected by high amounts of phosphorus, potash, or lime, but a certain amount of nitrogen seems to be necessary.

Howe ${ }^{69}$ (1914) said that ringing, while sometimes effective in inducing or increasing fruitfulness, is an unsafe stimulus to apply to fruit trees.

Gourley $^{57}$ (1914) reported that practically all methods of tillage treatment resulted in yields superior to those secured from the sod plots. In making a detailed study of the fruit spurs, this author ${ }^{58}$ (1915) found that the spur having a fruit bud upon it possessed a greater supply of starch than one without a fruit bud. The leaf area of a spur is always greater during the non-bearing year. Thinning experiments with the Baldwin did not give appreciable results so far as the regular bearing of the tree was concerned.

Sears ${ }^{128}$ (1914) agreed with Thomas $^{138}$ (1914) that rank growth is always opposed to fruitfulness since an abundance of plant food is essential to blossom formation. He further stated that the effect of summer pruning is not well understood-it depends upon the time, nature, and extent of the treatment,--but Drinkard ${ }^{38}$ (1915) and Batchelor and Goodspeed ${ }^{15}$ (1915) recommended summer pruning as a means of stimulating fruitfulness.

Alderman and Auchter ${ }^{3} 4$ (1916-17) in a series of experiments in West Virginia came to the general conclusion that heavy dormant pruning on young trees delays the bearing age while lighter pruning 
hastens it. In the case of old trees, however, vigorous pruning stimulates fruit production. They found that corrective dormant pruning was more effective in stimulating fruitfulness than summer pruning. Auchter ${ }^{6}$ (1917) states "thinning does not influence subsequent crops nor cause trees naturally biennial in bearing habit to bear each year."

From the work of Lewis ${ }^{91}$ (1915), Gardner ${ }^{47}$ (1915), Kraus ${ }^{79}$ (1915), Magness ${ }^{89}$ (1916), Bradford ${ }^{18}$ (1915), and Yeager ${ }^{151}$ (1916) of the Oregon agricultural experiment station, the following general conclusions may be drawn: A large percentage of the spurs bear only once in two years. Varieties fruiting on the newer parts are more regular bearers than those which fruit on the older portions. The condition of the tree as a whole determines whether a spur will fruit two years in succession. There is a correlation between the size of a spur and its productiveness but the floriferousness of a spur lessens as the spur becomes older. Fruit bud formation is due to a fair amount of adjacent leaf surface since the plant foods are stored up near the point of synthesis, a state of affairs making each twig more or less independent of the remainder of the tree. The greatest effects of pruning are manifested near the pruning cut. Summer pruning stimulates fruit bud formation near the base of the pruned twig only, and not thruout the body of the tree where the fruit spurs have already become well established.

Winkler ${ }^{148}$ (1916) concluded that under conditions favorable to enzyme action, vegetative growth predominates, while conditions inhibiting enzyme activity are favorable to reproductive activity. An accumulation of carbohydrates is given as one condition bringing about the cessation of enzyme action.

According to Pickering ${ }^{115}$ (1916) it is unproven that fruiting is due to a gradual accumulation of the plant reserves which become exhausted thru the production of a heavy crop. He concludes that the great variation found in the size of crops borne over a series of years is due to atmospheric conditions more than to any other factor even tho there is a tendency to alternation in certain varieties.

Retardation of growth always results in an increase in the starch proportion of the parts above ground,-at least, these are the results reported by Hartwell ${ }^{64}$ (1916) after working with the potato.

Barker and Lees ${ }^{12}$ (1916) reported that different degrees of dormant pruning result in practically an equal number of fruit buds being formed but that these buds are differently distributed on the tree.

Heinicke $^{66}$ (1917) stated that a dry sunny season is favorable for fruit bud production. $\mathrm{He}$ also found that bearing spurs are 
always heavier in weight than non-bearing spurs and that the greatest leaf area is found on the spurs with the greatest amount of connecting tissue. The age of the spur from two to four or five years apparently has little effect on its fruitfulness.

The established habit of the tree is far more influential upon the fruitfulness than the kind or extent of the pruning, according to Kains $^{73}$ (1917). Twig and small branch pruning, however, tend both to thin the fruit and favor regular annual bearing.

Butler $^{22}$ (1917) said that the theory that alternation is due to exhaustion has little or no foundation, but that it is a natural phenomenon to be predicated from the mode of flowering. Flower bud development, no matter on what kind of a branch, always occurs where six to eight sessile leaves have developed in a single period of vegetation. A slow, quick maturing, sessile growth, due to a scant but sufficient moisture supply, coupled with a vigorous photosynthetic activity is responsible for flower bud development. In his opinion small yearly departures from the mean growth will result in a more uniform production.

\section{GENERAI STATEMENT OF THE PROBLEM}

The apple yield of the entire United States shows a wide variation from year to year as the following table will indicate.

Table 1.-Annual Production of Apples in U. S.*

\begin{tabular}{|c|c|c|c|c|}
\hline & Year & $\begin{array}{l}\text { Yield } \\
\text { Barrels }\end{array}$ & Year & $\begin{array}{l}\text { Yield } \\
\text { Barrels }\end{array}$ \\
\hline 1909 & 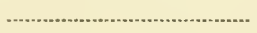 & $48,707,000$ & 1913. & $48,470,000$ \\
\hline 1910 & 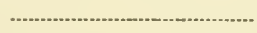 & $47,213,000$ & $1914 \ldots \ldots \ldots$ & $84,400,000$ \\
\hline 1911 & 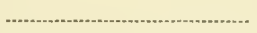 & $71,340,000$ & 1915 & $76,670,000$ \\
\hline 1912 & 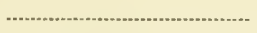 & $78,407,000$ & 1916 & $67,415,000$ \\
\hline
\end{tabular}

*Yearbook, U. S. D. A., 1916, p. 635.

The foregoing variation is probably to be expected when it is considered that allowances must be made for the wide ranges of both soil and climate over which the apple is grown in this country, and also because of the increased plantings. Unfavorable conditions in any one section are likely to be balanced by favorable ones in another, and so, on the whole, the foregoing figures do not represent the actual variation in yield which may be expected in any particular section. 
When the Missouri yield alone is considered even a greater variation than that shown in Table 1 is found. This smaller area represents more nearly uniform conditions and hence indicates the degree of difference which is often found in apple yields.

Table 2.-Annual Pronuction of Apples in Missouri*

\begin{tabular}{|c|c|c|c|c|}
\hline & Year & $\begin{array}{l}\text { Yield } \\
\text { Barrels }\end{array}$ & Year & $\begin{array}{c}\text { Yield } \\
\text { Barrels }\end{array}$ \\
\hline 1889 & & $2,899,000$ & $1903 \ldots$ & $2,067,000$ \\
\hline 1890 & 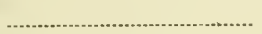 & $2,420,000$ & $1904 \ldots \ldots \ldots \ldots$ & $3,233,000$ \\
\hline 1891 & 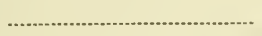 & $3,220,000$ & $1905 \ldots \ldots \ldots$ & $2,100,000$ \\
\hline 1892 & 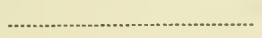 & $1,381,000$ & $1906 \ldots$ & $6,667,000$ \\
\hline 1893 & 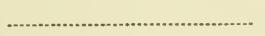 & 936,000 & $1907 \ldots \ldots \ldots \ldots \ldots \ldots$ & 433,000 \\
\hline 1894 & 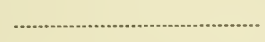 & $2,569,000$ & 1908 & $2,033,000$ \\
\hline 1895 & 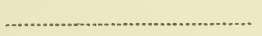 & $4,816,000$ & 1909 & $3,323,000$ \\
\hline 1896 & 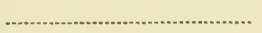 & $3,780,000$ & 1910 & $2,533,000$ \\
\hline 1897 & (1) & $3,599,000$ & $1911 \ldots \ldots$ & $3,867,000$ \\
\hline 1898 & 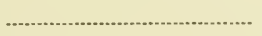 & 784,000 & $1912 \ldots \ldots$ & $6,400,000$ \\
\hline 1899 & 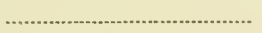 & $2,165,000$ & 1913.................. & $2,633,000$ \\
\hline 1900 & 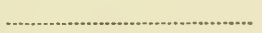 & $2,767,000$ & 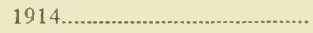 & $4,167,000$ \\
\hline 1901 & ‥1- & $3,500,000$ & $1915 \ldots \ldots$ & $6,287,000$ \\
\hline 1902 & 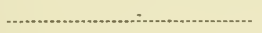 & $3,900,000$ & 1916 & $2,700,000^{* *}$ \\
\hline
\end{tabular}

*Missouri Bureat of Labor Statistics Report 37, 1915, p. 286.

** Yearbook U. S. D. A. 1916, p. 635.

An examination of the foregoing table reveals the interesting fact that, as a rule, the heavy yield occurred every third year. For instance, the years 1915, 1912, 1909, and 1906, all showing heavy yields, are invariably followed by a relatively light crop which in turn is followed by a medium yield which, apparently, leads up to the heavy production again. The same is shown to some extent for the earlier years also, but here such regularity can hardly be expected since during the period 1889 to 1899 very extensive plantings were being made and each year in that period showed a correspondingly greater number of trees in bearing. Such a state of affairs would naturally interfere with the regular sequence of bearing. However, the yields for the later years, which probably are more accurate than the others, represent the production of a more uniform number of trees and consequently may be considered as more representative of the way in which trees normally bear.

From the foregoing it is evident that the question of fruitfulness in apples is a very important one to the fruit grower who demands regular annual crops in order that his business may be a stable one.

A search of the literature previous to the initiation of this project revealed the fact that no particular attention had ever been 
given to a study of the individual fruit spurs. Previous investigators have based their opinions with respect to spur behavior, largely upon general observations and conclusions. Casual observations made by fruit growers generally have indicated that there is probably a correlation between the previous performance of a spur and its later fruitfulness, but data either confirming or contradicting this view have not been recorded.

In the light of the above facts, when this investigation was begun in 1913, it seemed advisable to center the attention upon the individual fruiting branches rather than to consider the performance of the tree or orchard as a whole. It seemed only logical to look in this direction for an answer to the question, Is the alternation of a Gano tree due to the inability of the individual spur to blossom and fruit two years in succession, or to some other factor, or factors? The question also arises as to whether the regular bearing of the Jonathan is caused by the fact that only a relatively small proportion of the spurs blossom any one season. Here again an answer must be sought by examining the fruit spurs and not by casual observation of the entire tree.

While the general object of this investigation has been to determine the effect of certain conditions and practices upon the development and performance of the individual fruit spur or branch, the following specific objects may be mentioned:

1. To determine whether an individual spur or branch blossoms two or more years in succession, in alternate years, or only once in its life history as a fruiting part.

2. To determine whether there is a correlation between the concentration of plant sap and stored reserves in bearing and nonbearing parts, and the observed bearing or non-bearing condition.

3. To correlate the leaf area of a spur with the fruiting habit that it possesses.

4. To observe the exact effect of girdling upon the concentration of sap in various parts of the trees.

5. To determine the effect of fertilizers upon dwarf trees planted in pots.

6. To record the osmotic strength of sap from different parts of trees grown under different systems of tillage.

7. To note the effect of certain systems of pruning upon the formation and development of the fruiting parts.

8. To note the effect of etherization upon the fruiting parts of young trees. 


\section{SPUR PERFORMANCE RECORDS}

In order to determine accurately the exact behavior of the individual spurs, it is essential to keep performance records of the spurs over a series of years. Accordingly, in the fall of 1913 a suitable label was attached to each spur that had produced a fruit that year. (Fig. 1.) This labeling was carried out systematically upon one tree each of the Jonathan, Gano and Rome varieties. These trees were located on the Forticultural Grounds of the Missouri Experiment Station. They were approximately eighteen years old and apparently in full health and vigor.

In the spring of 1914 , labels were attached to all of the blossoming spurs on the same trees, these labels being so marked that they could be distinguished from those attached the previous season. At the end of the season still another distinguishing mark was made upon the labels attached to the fruiting spurs. These marks were so made that by an exanination of the label it was possible to determine the exact behavior of that spur during the past year. The results of the first year's observations are:

Variety Gano

Number of spurs fruiting in $1913 \ldots \ldots \ldots . .598$

Number of same spurs blooming in 1914.. 49

Percentage $\ldots \ldots \ldots \ldots \ldots \ldots \ldots \ldots \ldots . . . .2$

Rome

223

19

8.5
Jonathan 228 36 15.8

These data show distinctly that only a very small percentage of the spurs which fruit one season will even blossom the next year. However, there is shown a considerable difference in the behavior of the spurs upon the different varieties. Thus, it will be seen in the case of the Jonathan, the ability to blossom in the season immediately following the one in which a fruit is matured, is shown in nearly twice as great a proportion as in either the Rome or Gano. (The greater number of fruits on the Gano tree was probably due, at least to some degree, to the fact that it was a larger tree than either of the others.)

From these observations as a starting point the work was continued during the seasons of 1915,1916 , and 1917 , so that in all this report covers a period of five years' work. Labels were attached to blossoming and fruiting spurs during these seasons so that at the end of the period it was possible to tell exactly how each spur had behaved each season since the observations were begun. The variety list was also extended so as to include Winesap, Grimes, and York, thus giving three varieties which are more or less regular 
bearers and three that exhibit alternation under ordinary conditions. Some later observations were also made upon fourteen-year-old trees of various varieties growing in the famous loess soil along the Missouri River.

Obviously, it would be almost impossible to record the performance of every spur upon every tree under observation. Hence, in the following figures no attempt has been made to include all of them. In each case, however, the number taken has been large enough to preclude accidental variation, and since they were taken from various parts of the tree so as to include all the different conditions found on the tree, they may be taken as being representative of the tree as a whole.

In Tables 3 to 13 inclusive, an attempt has been made to systematize the blossoming records secured on the above trees. These tables represent really the summary of still longer tables, and in order to simplify them, no account has been taken of the spurs which both blossom and fruit in distinction to those which blossom only. Since only a limited number of combinations are possible for each spur's performance during the five-year period, the spurs showing the same sequence of blooming and non-blooming have been grouped together. New spurs are, of course, being added to the tree each year, so it must be remembered that the following records represent the behavior of the present spur system of the tree and not the system that was on the tree five years ago when the investigation began. Many of the spurs which were fruiting at that time have now developed into larger branches upon which other fruit spurs are borne.

In the tables, the first five columns contain a record of the behavior of the spur during the past five years, while the right-hand column indicates the number of spurs exhibiting that particular combination. The letter " $\mathrm{B}$ " represents in each case a blossom cluster for that particular season, while a blank indicates that no blooms were shown. It might be noted that the record for the year 1913 indicates, in the main, only those spurs which fruited that season altho an attempt was made to include all of those that blossomed. However, since it was sometimes quite difficult to be sure upon this point this explanation is given. The last line in each table represents the percentage of blossome, out of the total number, which blossomed in the given years. 
Table 3.-Performance Record of Individual Spurs From a Jonathan Tree Grown in Clay loam Soil

\begin{tabular}{|c|c|c|c|c|c|}
\hline 1913 & 1914 & 1915 & 1916 & 1917 & $\begin{array}{l}\text { No.of } \\
\text { Spurs }\end{array}$ \\
\hline$\ldots$ & .... & .... & .... & B & 333 \\
\hline .... & $\ldots$. & ... & B & B & 86 \\
\hline -..- & .... & B & B & B & 41 \\
\hline -... & B & B & $B$ & B & 3 \\
\hline .... & $\mathrm{B}$ & $\ldots$. & B & B & 59 \\
\hline B & .... & $\ldots$ & $B$ & B & 2 \\
\hline$\ldots$. & ... & B & $\ldots$. & B & 238 \\
\hline$\ldots$ & B & B & $\ldots$. & $B$ & 21 \\
\hline B & B & B & $\ldots$. & B & 2 \\
\hline B & .... & $B$ & $\ldots$. & B & 97 \\
\hline .... & B & -... & $\ldots$. & B & 66 \\
\hline B & B & .... & ... & B & 1 \\
\hline B & $\ldots$. & $\ldots$. & .... & B & 3 \\
\hline .... & .... & $\ldots$ & B & .... & 137 \\
\hline .... & $\ldots$ & $\mathrm{B}$ & B & .... & 47 \\
\hline$\ldots$. & B & B & B & .... & 11 \\
\hline B & $\ldots$. & $\mathrm{B}$ & B & $\ldots$ & 5 \\
\hline .... & B & $\ldots$. & B & $\ldots$ & 101 \\
\hline B & .... & $\ldots$ & B & $\ldots$. & 2 \\
\hline ...- & $\ldots$ & B & $\ldots$. & .... & 61 \\
\hline .... & B & B & .... & $\ldots$ & 5 \\
\hline B & $\ldots$ & B & .... & .... & 9 \\
\hline .... & B & .... & $\ldots$. & .... & 15 \\
\hline B & $\ldots$ & $\cdots$ & -... & $\cdots$ & 1 \\
\hline $0 \%$ & $21.1 \%$ & $40.1 \%$ & $37.3 \%$ & $70.7 \%$ & 1346 \\
\hline
\end{tabular}

Table 5.-Performance Record of Individual Spurs From a Grimes Tree Grown in Clay Loam Soli.

\begin{tabular}{|c|c|c|c|c|c|}
\hline 1913 & 1914 & 1915 & 1916 & 1917 & $\begin{array}{l}\text { No.of } \\
\text { Spurs }\end{array}$ \\
\hline$\cdots$ & $\cdots$ & $\ldots$ & $\ldots$. & B & 250 \\
\hline -.-- & .... & ... & B & B & 21 \\
\hline -.. & $\ldots$ & B & B & B & 9 \\
\hline .... & $\mathrm{B}$ & B & B & B & 1 \\
\hline$\ldots$. & B & .... & B & B & 5 \\
\hline .... & .... & B & ... & B & 185 \\
\hline B & -... & B & $\ldots$. & B & 42 \\
\hline ... & B & $\ldots$. & .... & B & 2 \\
\hline B & $\mathrm{B}$ & $\ldots$. & .... & B & 2 \\
\hline B & $\ldots$ & $\cdots$ & $\ldots .$. & $\mathrm{B}$ & 2 \\
\hline$\ldots$. & $\ldots$. & $\ldots$. & B & .... & 110 \\
\hline .... & .... & B & B & .... & 17 \\
\hline .... & B & B & B & $\ldots$. & 1 \\
\hline$\ldots$. & B & $\ldots$ & B & .... & 12 \\
\hline$\ldots .$. & .... & B & $\ldots$. & .... & 197 \\
\hline$\ldots$ & B & B & ... & $\ldots$. & 12 \\
\hline $\mathrm{B}$ & $\cdots$ & $\mathrm{B}$ & $\cdots$ & .... & 25 \\
\hline$\ldots$ & B & $\ldots$. & .... & .... & 3 \\
\hline B & ... & .... & $\cdots$ & $\cdots$ & 5 \\
\hline $8.3 \%$ & $4.4 \%$ & $42.7 \%$ & $17.2 \%$ & $57.0 \%$ & 901 \\
\hline
\end{tabular}

Table 4.-Performance Record of Individual Spurs From a Jonatilan Tree Grown in Loess Soll

\begin{tabular}{|c|c|c|c|c|c|}
\hline 1913 & 1914 & 1915 & 1916 & 1917 & $\begin{array}{l}\text { No.of } \\
\text { Spurs }\end{array}$ \\
\hline .... & .... & .... & .... & B & 134 \\
\hline$\ldots .$. & .... & .... & B & B & 92 \\
\hline$\ldots$. & ..-. & $\mathrm{B}$ & B & B & 20 \\
\hline .... & B & B & B & B & 1 \\
\hline $\mathrm{B}$ & B & B & B & B & 1 \\
\hline$\dot{B}$ & .... & B & B & B & 3 \\
\hline .... & B & .... & B & B & 12 \\
\hline B & $\ldots$. & $\ldots$. & B & B & 2 \\
\hline .... & .... & B & $\ldots$. & B & 51 \\
\hline $\mathrm{B}$ & ... & $\mathrm{B}$ & .... & B & 9 \\
\hline .... & $\mathrm{B}$ & .... & .... & B & 2 \\
\hline$\ldots$ & $\ldots .$. & $\ldots$. & B & .... & 155 \\
\hline$\ldots$ & $\ldots$ & B & B & .... & 10 \\
\hline .... & B & B & B & .... & 1 \\
\hline B & .... & B & B & .... & 1 \\
\hline .... & B & $\ldots$. & B & .... & 44 \\
\hline B & B & $\ldots$ & B & .... & 1 \\
\hline .... & .... & B & .... & $\ldots$ & 15 \\
\hline B & $\ldots$. & $\mathrm{B}$ & .... & ... & 2 \\
\hline$\cdots$ & B & $\ldots$. & $\cdots$ & $\cdots$ & 1 \\
\hline $3.4 \%$ & $11.0 \%$ & $20.4 \%$ & $61.6 \%$ & $58.7 \%$ & 557 \\
\hline
\end{tabular}

TABle 6.-Performance Records of Individual Spurs From a IVinesap Tree, in Clay loam Soll

\begin{tabular}{|c|c|c|c|c|c|}
\hline 1913 & 1914 & 1915 & 1916 & 1917 & $\begin{array}{l}\text { No.of } \\
\text { Spurs }\end{array}$ \\
\hline .... & .... & $\ldots$ & $\ldots$ & B & 188 \\
\hline -..- & -..- & $\ldots$ & B & B & 110 \\
\hline .... & .... & B & B & B & 70 \\
\hline$\ldots$. & B & B & B & B & 9 \\
\hline B & .... & B & B & $B$ & 19 \\
\hline$\ldots$ & B & $\ldots$. & B & B & 76 \\
\hline B & ... & $\cdots$ & B & B & 1 \\
\hline .... & $\ldots$. & B & .... & B & 64 \\
\hline -..- & B & B & $\ldots$. & B & 1 \\
\hline B & .... & B & .... & B & 6 \\
\hline .... & B & .... & ... & B & 1 \\
\hline$\cdots$ & ... & .... & B & $\ldots$. & 49 \\
\hline .... & .... & B & B & .... & 11 \\
\hline B & ... & B & B & .... & 3 \\
\hline$\ldots$. & B & $\cdots$ & B & .... & 34 \\
\hline$\cdots$ & -... & B & $\ldots$ & .... & 11 \\
\hline .... & B & B & $\ldots$. & $\ldots$. & 2 \\
\hline B & $\ldots$. & B & .... & $\ldots$. & 3 \\
\hline ... & B & -... & -... & .... & 3 \\
\hline $4.1 \%$ & $19.5 \%$ & $30.1 \%$ & $56.1 \%$ & $82.4 \%$ & 661 \\
\hline
\end{tabular}


TABle 7.-Performance Records of Indvidual Spurs from a Winesap Tree Grown IN LOESS SOIL.

\begin{tabular}{|c|c|c|c|c|c|}
\hline 1913 & 1914 & 1915 & 1916 & 1917 & $\begin{array}{l}\text { No.of } \\
\text { Spurs }\end{array}$ \\
\hline .... & $\ldots$ & .... & ..... & B & 102 \\
\hline$\ldots$. & .... & .... & $\mathrm{B}$ & $\mathrm{B}$ & 56 \\
\hline .... & $\ldots$. & B & B & B & 21 \\
\hline .... & B & B & $\mathrm{B}$ & B & 8 \\
\hline $\mathrm{B}$ & .... & $\mathrm{B}$ & $\mathrm{B}$ & B & 5 \\
\hline .... & B & .... & $\mathrm{B}$ & B & 14 \\
\hline B & B & $\ldots .$. & B & $B$ & 5 \\
\hline .... & $\ldots$. & B & .... & B & 27 \\
\hline$\ldots$. & B & B & $\ldots$. & B & 9 \\
\hline B & $\ldots$. & B & $\ldots$. & B & 7 \\
\hline$\cdots$ & B & $\ldots$. & $\ldots$. & B & 3 \\
\hline .... & $\ldots$ & $\ldots$. & $\mathrm{B}$ & $\cdots .$. & 34 \\
\hline -... & $\ldots$ & B & $\mathrm{B}$ & $\ldots$. & 10 \\
\hline .... & $\mathrm{B}$ & B & B & $\ldots$. & 4 \\
\hline$B$ & $\ldots$. & B & B & .... & 1 \\
\hline .... & $B$ & .... & $\mathrm{B}$ & $\ldots$. & 6 \\
\hline $\mathrm{B}$ & B & .... & $\mathrm{B}$ & .... & 2 \\
\hline$\ldots$ & .... & B & $\cdots$ & $\ldots$ & J \\
\hline $6.0 \%$ & $16.1 \%$ & $28.8 \%$ & $55.8 \%$ & $81.6 \%$ & 315 \\
\hline
\end{tabular}

TABLE 9.-Performance Records of Indvidual SpUrs From a York Tree Grown in Clay loam Soil

\begin{tabular}{|c|c|c|c|c|c|}
\hline 1913 & 1914 & 1915 & 1916 & 1917 & $\begin{array}{l}\text { No.of } \\
\text { Spurs }\end{array}$ \\
\hline .... & .... & .... & ..... & B & 81 \\
\hline .... & .... & .... & $\mathrm{B}$ & B & 2 \\
\hline .... & $\ldots$. & B & B & $\mathrm{B}$ & 1 \\
\hline$\cdots$ & B & $\ldots$. & $\mathrm{B}$ & B & 3 \\
\hline ... & $\ldots$ & B & .... & B & 48 \\
\hline$\cdots .$. & B & B & .... & B & 1 \\
\hline $\mathrm{B}$ & ... & $\mathrm{B}$ & $\ldots$. & B & 23 \\
\hline B & $\ldots$. & .... & $\cdots .$. & B & 7 \\
\hline .... & $\ldots$. & $\ldots$ & B & $\ldots$ & 11 \\
\hline .... & .... & B & B & $\ldots$ & 4 \\
\hline$\cdots$ & $\ldots$. & B & .... & $\ldots$. & 8 \\
\hline B & ...- & B & .... & $\ldots$. & 1 \\
\hline $6.3 \%$ & $2.1 \%$ & $45.2 \%$ & $11.2 \%$ & $87.3 \%$ & 190 \\
\hline
\end{tabular}

TABLE 8.-Performance Records of Imdividual SpUrs From a Rone trex Grown in Clay loam Soll

\begin{tabular}{|c|c|c|c|c|c|}
\hline 1913 & 1914 & 1915 & 1916 & 1917 & $\begin{array}{l}\text { No.of } \\
\text { Spurs }\end{array}$ \\
\hline .... & $\ldots$ & -... & .... & B & 3 \\
\hline$\ldots$. & $\ldots$. & B & $\ldots$. & B & 1 \\
\hline$\ldots$ & $\ldots$. & $\ldots$. & B & $\ldots$. & 428 \\
\hline .... & $\ldots$ & B & $\mathrm{B}$ & .... & 48 \\
\hline$\ldots$. & B & $\mathrm{B}$ & B & $\ldots$. & 4 \\
\hline B & .... & B & B & .... & 2 \\
\hline$\ldots$. & $\mathrm{B}$ & $\ldots$. & B & .... & 313 \\
\hline B & B & .... & B & $\ldots$. & 2 \\
\hline B & .... & $\ldots$. & B & -..- & 1 \\
\hline$\ldots$. & $\ldots$. & B & .... & $\ldots$. & 95 \\
\hline$\ldots$ & $B$ & $B$ & $\ldots$. & .... & 4 \\
\hline B & .... & $\mathrm{B}$ & $\ldots$. & $\ldots$. & 13 \\
\hline$\cdots$ & B & $\cdots$ & $\cdots$ & -... & 5 \\
\hline $1.9 \%$ & $35.7 \%$ & $18.1 \%$ & $86.8 \%$ & $0.3 \%$ & 919 \\
\hline
\end{tabular}

Table 10.-Performance Records of Individual Spurs From a York Tree Grown in Loess Soll

\begin{tabular}{|c|c|c|c|c|c|}
\hline 1913 & 1914 & 1915 & 1916 & 1917 & $\begin{array}{l}\text { No.of } \\
\text { Spurs }\end{array}$ \\
\hline .... & .... & -... & .... & B & 47 \\
\hline .... & .... & .... & B & B & 5 \\
\hline .... & .... & B & .... & B & 4 \\
\hline B & $\ldots$ & B & .... & B & 1 \\
\hline B & $\ldots$. & $\ldots$. & .... & $\mathrm{B}$ & 1 \\
\hline$\ldots$ & .... & $\ldots$. & B & $\ldots$ & 180 \\
\hline$\ldots$. & .... & $B$ & B & .... & 31 \\
\hline$\ldots$. & B & B & B & .... & 2 \\
\hline B & B & B & $\mathrm{B}$ & .... & 1 \\
\hline .... & .... & B & B & .... & 22 \\
\hline B & .... & B & B & $\ldots$. & 4 \\
\hline -.. & B & .... & B & $\ldots$ & 5 \\
\hline .... & .... & $\mathrm{B}$ & .... & $\ldots$ & 17 \\
\hline .... & B & B & .... & $\ldots$ & 1 \\
\hline B & .... & $\mathrm{B}$ & .... & .... & 1 \\
\hline$\ldots$. & B & $\ldots$. & .... & ... & 3 \\
\hline B & B & .... & .... & .... & 1 \\
\hline $2.7 \%$ & $3.9 \%$ & $25.7 \%$ & $76.7 \%$ & $14.7 \%$ & 326 \\
\hline
\end{tabular}


Table 11.-Performance Records of Individual Spurs from a Gawo Tree Grown in Clay Loam Soll

\begin{tabular}{|c|c|c|c|c|c|}
\hline 1913 & 1914 & 1915 & 1916 & 1917 & $\begin{array}{l}\text { No.of } \\
\text { Spurs }\end{array}$ \\
\hline$\ldots$. & $\cdots$ & … & .... & $B$ & 7 \\
\hline$\ldots$ & $\ldots$. & B & .... & B & 1 \\
\hline$\ldots$ & .... & $\ldots$. & B & $\ldots$. & 1047 \\
\hline$\ldots$. & $\ldots$. & B & B & $\ldots$. & 8 \\
\hline .... & B & B & B & $\ldots$. & 4 \\
\hline B & ...- & B & B & $\ldots$. & 2 \\
\hline .... & B & $\ldots$. & B & $\ldots$. & 545 \\
\hline$B$ & .... & .... & B & ... & 26 \\
\hline .... & ... & B & .... & ... & 47 \\
\hline .... & B & B & $\ldots$. & $\ldots$. & 1 \\
\hline B & ... & B & .... & $\ldots$. & 6 \\
\hline .... & B & .... & $\ldots$ & $\ldots$. & 130 \\
\hline B & B & $\ldots .$. & $\ldots$. & $\ldots$. & 3 \\
\hline B & ... & $\ldots$. & $\ldots$ & $\cdots$ & 37 \\
\hline $3.9 \%$ & $36.4 \%$ & $3.6 \%$ & $87.1 \%$ & $0.5 \%$ & 1864 \\
\hline
\end{tabular}

TAble 13.-Performance Records of INdividual Spurs From a Gamo Tree

(No. 2) GRown in Loess SoIL*

\begin{tabular}{|c|c|c|c|c|c|}
\hline 1913 & 1914 & 1915 & 1916 & 1917 & $\begin{array}{l}\text { No.of } \\
\text { Spurs }\end{array}$ \\
\hline .... & .... & .... & .... & B & 22 \\
\hline .... & .... & .... & B & $B$ & 51 \\
\hline .... & B & .... & B & B & 35 \\
\hline B & .... & $\ldots$ & B & B & 1 \\
\hline .... & $\ldots$. & B & $\ldots$. & B & 6 \\
\hline B & -... & B & .... & B & 1 \\
\hline$\cdots$ & B & ... & ... & B & 4 \\
\hline .... & $\ldots$. & $\ldots$ & B & $\ldots$. & 83 \\
\hline -... & $\ldots$. & B & B & .... & 8 \\
\hline B & $\ldots$. & B & B & ... & 1 \\
\hline .... & B & $\ldots$. & B & $\ldots .$. & 15 \\
\hline B & $B$ & $\ldots$. & B & $\ldots$ & 1 \\
\hline B & $\ldots$ & $\ldots$ & B & .... & 1 \\
\hline -... & $\ldots$. & B & .... & $\cdots$ & 1 \\
\hline $2.1 \%$ & $23.9 \%$ & $7.4 \%$ & $85.2 \%$ & $52.1 \%$ & 230 \\
\hline
\end{tabular}

* Blossoms practically all destroyed in 1916 by spray solution. (See page 24 for further explanation).

An examination of the preceding tables shows that the varieties studied may be divided roughly into two classes, one of which produces a fair supply of blossoms each year but with no exceedingly productive seasons, while the other exhibits a very high percentage of blossoms one season and a comparatively low one the next. Jona- 
than, Winesap, and Grimes belong to the former, and Rome, York, and Gano to the latter group. The varieties of the first group are usually considered as annual bearers, while the others show rather marked alternation.

The difference in the behavior of these two groups is brought out more clearly in Table 14, which is a summary of the preceding tables.

Table 14.-Percentage of Fruit Spurs Biossoming in the Various Seasons. (1913-1917)

(Summary of Tables 3 to 13.)

\begin{tabular}{|c|c|c|c|c|c|c|c|}
\hline \multirow{2}{*}{ Variety } & \multirow{2}{*}{$\begin{array}{l}\text { Soil } \\
\text { Type } \\
\text { WVhere } \\
\text { Grown }\end{array}$} & \multirow{2}{*}{$\begin{array}{l}\text { Total } \\
\text { No. } \\
\text { of } \\
\text { Spurs }\end{array}$} & \multicolumn{5}{|c|}{ Percentage Distribution of Blossom } \\
\hline & & & 1913 & 1914 & 1915 & 1916 & 1917 \\
\hline Jonathan & Clay Loam & 1346 & 9.0 & 21.1 & 40.1 & 37.3 & 70.7 \\
\hline Jonathan & Loess & 557 & 3.4 & 11.3 & 20.4 & 61.6 & 58.7 \\
\hline Grimes & Clay Loam & 901 & 8.3 & 4.4 & 42.7 & 17.2 & 57.0 \\
\hline Winesap & Clay Loam & 661 & 4.1 & 19.5 & 30.1 & 56.1 & 82.4 \\
\hline Winesap ............. & Loess & 315 & 6.0 & 16.1 & 28.8 & 55.8 & 81.6 \\
\hline Roine & Clay Loam & 919 & 1.9 & 35.7 & 18.1 & 86.8 & 0.3 \\
\hline York & Clay Loam & 190 & 16.3 & 2.1 & 45.2 & 11.2 & 87.3 \\
\hline 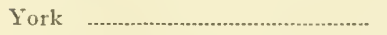 & Loess & 326 & 2.7 & 3.9 & 25.7 & 76.7 & 14.7 \\
\hline Gano & Clay Loam & 1864 & 3.9 & 36.4 & 3.6 & 87.1 & 0.5 \\
\hline 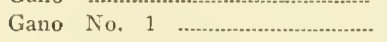 & Loess & 218 & 2.3 & 20.9 & 2.6 & 97.2 & 3.6 \\
\hline Gano No. $2^{*}$ & Loess & 230 & 2.1 & 23.9 & 7.4 & 85.2 & 52.1 \\
\hline
\end{tabular}

*Blossoms practically all destroyed in 1916 by spray solution.

It will be noted that the behavior in 1917 of the spurs on the tree, Gano No. 2, is in apparent contradiction to that of Gano No. 1. This may be explained by the fact that in 1916, at which time both trees had a heavy bloom, the spraying operations were so delayed that it was necessary to spray tree No. 2 when it was in full blossom. As a result, only a very small percentage of the blossoms set fruit, hence the spurs were able to mature fruit buds for the following year. That they did so, is evidenced by the amount of blossom carried by the tree in 1917. It is thus seen, notwithstanding the statements of some investigators to the contrary, that the bearing year may be changed, and, to this extent, is subject to the control of the horticulturist.

Attention is also called to the fact that the York tree growing in loess soil, produces its blossoms in the season alternating with the heavy fruit crop of the tree in the clay loam soil. Even in the same orchard this same variation in behavior is sometimes found. In each case, however, marked alternation is shown. It gives strength 
to the statement sometimes made that when alternation is once established, there is a great likelihood that it will be continued thru the following years, unless interrupted by accident or design.

Outside of the foregoing exceptions the varieties show very great similarity in their behavior in the different soil types. This is at least suggestive of the conclusion that after all the soil conditions do not affect markedly the behavior of the individual spurs with respect to their individual alternation.

With the idea of showing a little more clearly the behavior of the individual spurs, Tables 15 and 16 have been prepared. The first table indicates the percentage of the spurs now on the tree, which have produced blossom buds in successive seasons, while the second table shows the percentage of spurs which have blossomed in alternate years.

Table 15.-Percentage of Spurs Blussoming in Alternate. Seasons

\begin{tabular}{|c|c|c|c|c|c|c|}
\hline \multirow[t]{2}{*}{ Variety } & \multirow{2}{*}{$\begin{array}{l}\text { Soil } \\
\text { Type } \\
\text { Where } \\
\text { Grown }\end{array}$} & \multirow{2}{*}{$\begin{array}{l}\text { Total } \\
\text { No. } \\
\text { of } \\
\text { Spurs }\end{array}$} & \multicolumn{3}{|c|}{ Percentage Blooming in } & \multirow{2}{*}{$\begin{array}{l}\text { Total Per- } \\
\text { centage } \\
\text { Showing } \\
\text { Alternation }\end{array}$} \\
\hline & & & $1913-15$ & $1914-16$ & $1915-17$ & \\
\hline Jonathan & Clay Loam & 1346 & 0.6 & 7.6 & 26.6 & 34.8 \\
\hline Jonathan & Loess & 557 & 0.3 & 8.0 & 10.7 & 19.0 \\
\hline Grimes & Clay Loam & 901 & 2.7 & 1.3 & 21.8 & 25.8 \\
\hline Winesap & Clay Loatn & 661 & 0.4 & 5.1 & 10.9 & 16.4 \\
\hline Winesap .. & Loess & 315 & 0.0 & 2.5 & 13.6 & 16.1 \\
\hline Rome & Clay Loam & 919 & 1.4 & 34.2 & 0.1 & 35.7 \\
\hline (n................... & Clay Loam & 190 & 0.0 & 0.0 & 37.9 & 37.9 \\
\hline York & Loess & 326 & 0.0 & 1.5 & 1.5 & 3.0 \\
\hline Gano & Clay Loam & 1864 & 0.2 & 28.7 & 0.0 & 28.9 \\
\hline 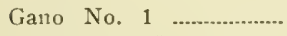 & Loess & 218 & 1.4 & 20.1 & 0.0 & 21.5 \\
\hline Gano No. $2^{*}$ & Loess & 230 & 0.0 & 7.4 & 3.0 & 10.4 \\
\hline
\end{tabular}

*Blossoms practically all destroyed in 1916 by spray solution.

Table 16.-Percentage of Spurs Blossoming in Successive Seasons

\begin{tabular}{|c|c|c|c|c|c|c|}
\hline \multirow[t]{2}{*}{ Variety } & \multirow{2}{*}{$\begin{array}{l}\text { Soil } \\
\text { Type } \\
\text { Where } \\
\text { Growil }\end{array}$} & \multirow{2}{*}{$\begin{array}{l}\text { Total } \\
\text { No. } \\
\text { of } \\
\text { Spurs }\end{array}$} & \multicolumn{3}{|c|}{ Percentage Blooming in } & \multirow{2}{*}{$\begin{array}{l}\text { Total Per- } \\
\text { centage } \\
\text { Showing } \\
\text { Succession }\end{array}$} \\
\hline & & & $1914-15$ & $1915-16$ & $1916-17$ & \\
\hline Jonathan & Clay Loam & 1346 & 0.3 & 4.6 & 14.1 & 19.0 \\
\hline Jonathan & Loess & 557 & 0.0 & 2.1 & 23.5 & 25.6 \\
\hline Grimes & Clay Loam & 901 & 1.3 & 1.9 & 3.9 & 7.1 \\
\hline Winesap & Clay Loam & 661 & 0.3 & 2.1 & 43.1 & 45.5 \\
\hline 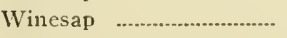 & Loess & 315 & 0.0 & 4.7 & 31.4 & 36.1 \\
\hline Rome & Clay Loam & 919 & 0.3 & 5.8 & 0.0 & 6.1 \\
\hline 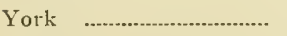 & Clay Loam & 190 & 0.0 & 2.1 & 3.1 & 6.2 \\
\hline York & Loess & 326 & 0.3 & 18.3 & 1.5 & 20.1 \\
\hline Gano & Clay Loam & 1864 & 0.0 & 0.8 & 0.0 & 0.8 \\
\hline Gano No. 1 .................... & Loess & 218 & 2.7 & 0.9 & 0.4 & 4.0 \\
\hline Gano No. $2^{*}$ & Loess & 230 & 37.8 & 2.9 & 0.0 & 40.7 \\
\hline
\end{tabular}

*Blossoms practically all destroyed in 1916 by spray solution. 
From Table 15 it will be noted that there are relatively slight differences between the different varieties in regard to the percentthe Jonathan tree, a regular bearer, has as great a percentage of age of spurs which alternate in their blooming habit; in other words, spurs which bloom only once in two years as the Gano, which is notorious as an alternate cropper. When trees grown on similar soils are compared, the difference is very slight, the only exception occurring in the case of the Winesap. The Winesap is really one of our most reliable regular annual bearers and an explanation for this may rest in the fact that only a small percentage of the spurs do alternate in their blooming habit. Gano No. 2 also shows a slight variation from the average as do also the York and Jonathan grown upon loess soil. This is perhaps to be expected since these trees as yet have hardly attained a fully established bearing age.

Table 16 exhibits by no means such close agreement of varieties as that noted for the preceding one but rather the varieties are again divided into two general groups. With the apparent exception of the Grimes, the varieties producing regular crops possess to a marked degree the ability to produce a blossom on the same spur two years in succession. This ability is exhibited to a higher degree in the Winesap than in the Jonathan, a performance which might be expected because of the small percentage of Winesap spurs which show alternation.

Examination of the performance records of the second group of varieties shows that only a very small proportion of the spurs are able to produce successive crops of blooms. The York grown in loess soil is seemingly an exception, as is also Gano No. 2. The latter case, however, is fully explained by the fact that the 1916 crop of blossoms was practically destroyed, and hence, the tree was able to mature a larger number than normal in 1917. In the case of the York, it may be said that local environmental conditions, as well as the younger age of the tree, probably played a very important part.

The fact brought out just above, which is that spurs on varieties which bear regularly are able to produce blossoms two years in succession in a high percentage of cases while alternate bearers are not, suggests an explanation for the figures recorded in Table 14 . The regularity of the blossom in the case of the first group is conceivably due to the fact that a great many of the spurs are able to produce blossoms two years in succession. Also, the inability of the second group of varieties to blossom two years in succession coupled with their exceedingly heavy production of blossoms one year will 


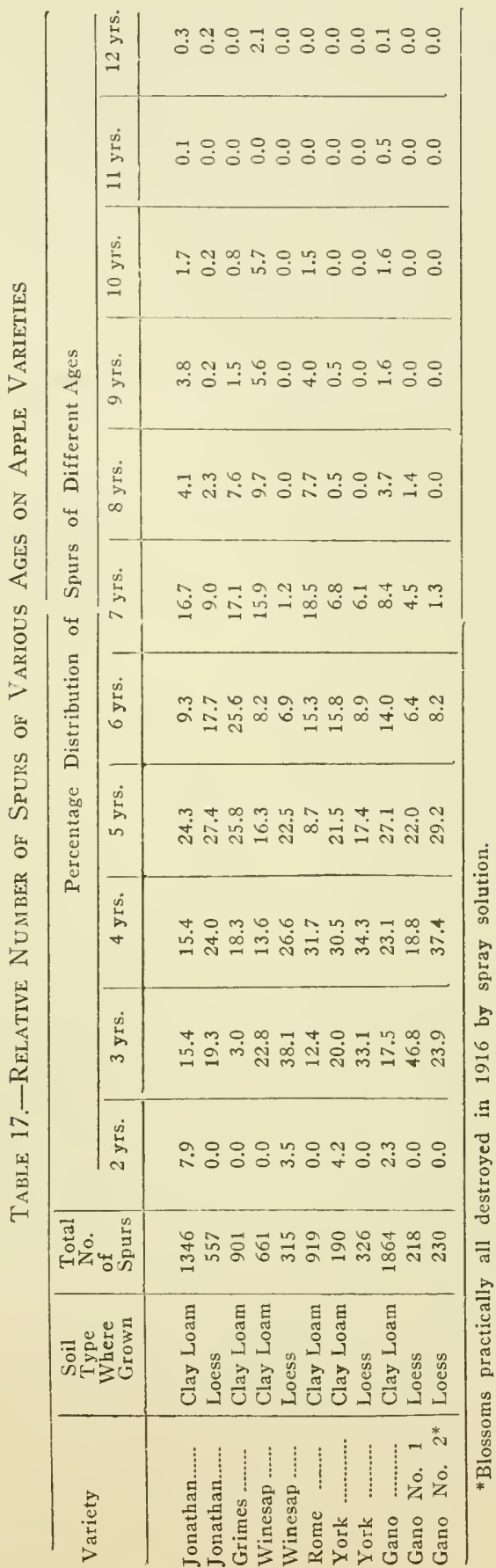


account for the small number of blooming spurs during the following season. Thus, the difference between alternating and nonalternating varieties seems to be due to the ability of spurs on the regular bearing sorts to blossom two years in succession.

While recording the performance record of the spurs, an attempt was also made to approximate their age by counting the number of scale scar rings upon the spur. In some instances the age given is simply an estimate. This is especially the case with the old spurs because after the age of six or seven is reached, it becomes difficult to be absolutely positive as to just how old the spur may be. Table 17 will serve to show the relative ages of the blossoming spurs on the various varieties.

It is of interest to observe that by far the greater part of the blossoming spurs in every case are between three and seven years of age. This holds true for both alternating and regular bearing sorts and hence leads to the conclusion that the age at which the spur begins to bear is of little significance in relation to the bearing habit of the variety.

Because of the youthfulness of a large part of the spurs, it is again noted that by far the greater part of the spurs present on the trees when these observations were begun are spurs no longer. They have developed into branches and many new spurs have been formed. A spur seems to be at its highest state of efficiency when from three to six or seven years of age.

\section{THE FOOD RESERVES OF FRUIT SPURS}

The amount of available plant food has long been considered as the determining factor in fruit bud formation but there seems to be very little evidence or actual data to support this view. It then has seemed worth while to compare as far as possible the plant food reserves of fruiting and non-fruiting spurs and their various parts, that is, their leaves and fruits.

There are two general methods by which the relative amounts of stored food in plant tissue may be determined, the first, by determining the concentration of the plant sap thru the use of the freezing point method, and the second, by making an actual chemical analysis of the parts under consideration. The former method was used extensively by both Chandler ${ }^{25}$ and Winkler ${ }^{148}$ at this Station, while the English investigators, Davis and Daisch ${ }^{33}$ employed the latter in the determination of plant carbohydrates. In the first method, it is not possible to calculate the absolute amount of materials 
present, only the relative proportions are indicated. Neither can the amount of starch be determined by this method. Through the use of the analytical method, however, both the identity and absolute amounts of the substances present can be determined if suitable methods are employed. Both methods have been used in this investigation, but, in either case, only for the determination of the relative amounts of the reserves rather than their absolute percentages.

1. Depressicn of the freezing point.-The sap for the determination of the freezing point depression was secured by grinding up the parts under consideration by means of a food chopper and then subjecting the ground material to considerable pressure. The material was enclosed in muslin before being placed in the pressing blocks. These blocks were of hardwood and so made that one of them just fit into a cavity in the side of the other. A jackscrew served as a means by which the pressure was applied. Figure 2 shows the various details of the press. The expressed sap was collected into a test-tube thru a small funnel.

After being expressed the sap was kept in a cool place until its freezing point could be determined. An ordinary Beckman thermometer was used and the low temperature secured thru the use of a salt and ice mixture. A small amount of sap was placed in a test tube, the amount being just sufficient to cover the bulb of the thermometer. The thermometer was then inserted and the tube plunged into the salt and ice. It was usually found to be advisable not to have this tube in direct contact with the ice because the cooling in that case was too rapid. Best results were secured by first inserting into the freezing mixture a tube slightly larger than the one containing the sap, and then placing the latter inside the former. An air jacket then surrounds the tube containing the sap and the thermometer. This will slightly retard the cooling and thus insure a more uniform cooling.

The depressions given in the following tables represent the difference between the freezing point of distilled water and the freezing point of the particular sap. The plant saps, being of a higher concentration, freeze at a lower temperature. The greater this concentration, the lower will be the freezing point, and hence, the greater the depression. It is assumed that the saps with the greater depression possess the greater supply of plant food. No attempt has been made to calculate the osmotic strength of the various saps but this could be very easily done by reference to the osmotic strength tables worked out by Harris and Gortner ${ }^{62}{ }^{63}$. 
Table 18 indicates the depressions which were found in the spur sap from spurs bearing or non-bearing in the years specified. In every case, an attempt was made to get spurs representative of these two conditions, the spurs being taken from the same branch as far as possible. Only the short iruiting branches were used, rarely were they more than three inches long. So far as outward appearance was concerned, the only difference between the two sets of spurs was that one group had fruited in the year specified and the other had not. After the spur material was ground, the sap was expressed as previously described.

Table 18.-Depression of Jonathan Fruit Spur Sap

\begin{tabular}{|c|c|c|c|c|}
\hline Date & $\begin{array}{l}\text { Bearing } \\
\text { previous } \\
\text { year }\end{array}$ & $\begin{array}{l}\text { Non-bearing } \\
\text { previous } \\
\text { year }\end{array}$ & $\begin{array}{l}\text { Bearing } \\
\text { same } \\
\text { year }\end{array}$ & $\begin{array}{l}\text { Non-bearing } \\
\text { same } \\
\text { year }\end{array}$ \\
\hline & $\begin{array}{l}\text { Degrees C. } \\
2.450\end{array}$ & $\begin{array}{l}\text { Degrees C. } \\
2.300\end{array}$ & Degrees C. & Degrees C. \\
\hline $\begin{array}{l}\text { February } 6,1915 \ldots \\
\text { February } 27,1915 \ldots \ldots \ldots\end{array}$ & 2.100 & 1.730 & (n)...... & (n) \\
\hline March $19,1915^{*} \ldots$ & 2.120 & 1.990 & 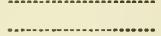 & ……............... \\
\hline April $4,1915^{*} \ldots \ldots$ & 2.370 & 2.170 & 年 & 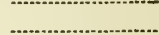 \\
\hline June $8,1915 \ldots \ldots \ldots$ & & & 1.865 & 1.855 \\
\hline June $21,1916 \ldots$ & 2.130 & 2.000 & 1.860 & 2.000 \\
\hline July $6, \quad 1916 \ldots$ & 1.200 & 1.340 & 1.200 & 1.200 \\
\hline July $15,1915^{*} \ldots \ldots$ & & & 1.200 & 1.330 \\
\hline July 17,1915 & 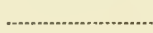 & n....... & 1.060 & 1.070 \\
\hline July 22,1916 & 1.355 & 1.340 & 1.225 & 1.530 \\
\hline July $31,1915 \ldots \ldots \ldots$ & & & 1.010 & 1.110 \\
\hline August 1,1916 & 1.265 & 1.210 & 1.250 & 1.400 \\
\hline August 17,1916 & 1.285 & 1.215 & 1.500 & 1.370 \\
\hline September 15, 1916 & 1.080 & 1.040 & 1.205 & 1.435 \\
\hline October $14,1916 \ldots$ & 1.290 & 0.910 & 1.995 & 1.945 \\
\hline
\end{tabular}

*Spurs from trees grown in loess soil.

A study of the figures in Table 18 shows that during a considerable portion of the year the sap from the bearing spurs and also sap from spurs fruiting during the preceding season, has a greater depression than sap from corresponding nonfruiting parts. This difference may not be large enough to be of special significance. It gives no conclusive proof to the claim that in a non-fruiting year the spur is accumtlating reserves for the next year's crop of buds. However, it may be possible that the greater part of the reserves are stored farther back from the end of the branch. Then, too, these data do not include a measure of the reserves which are stored up as starch.

The accompanying chart shows graphically the depressions recorded in Table 18. It is noticed that the sap of non-fruiting spurs is slightly more concentrated than the sap of a spur holding a fruit 
at that particular time. On the other hand, sap from spurs bearing the year previous to the determination shows consistently a greater concentration than the sap from corresponding parts that did not fruit during the preceding season. This difference gradually disappears, however, and apparently both kinds of spurs reach a similar degree of concentration about July 1.

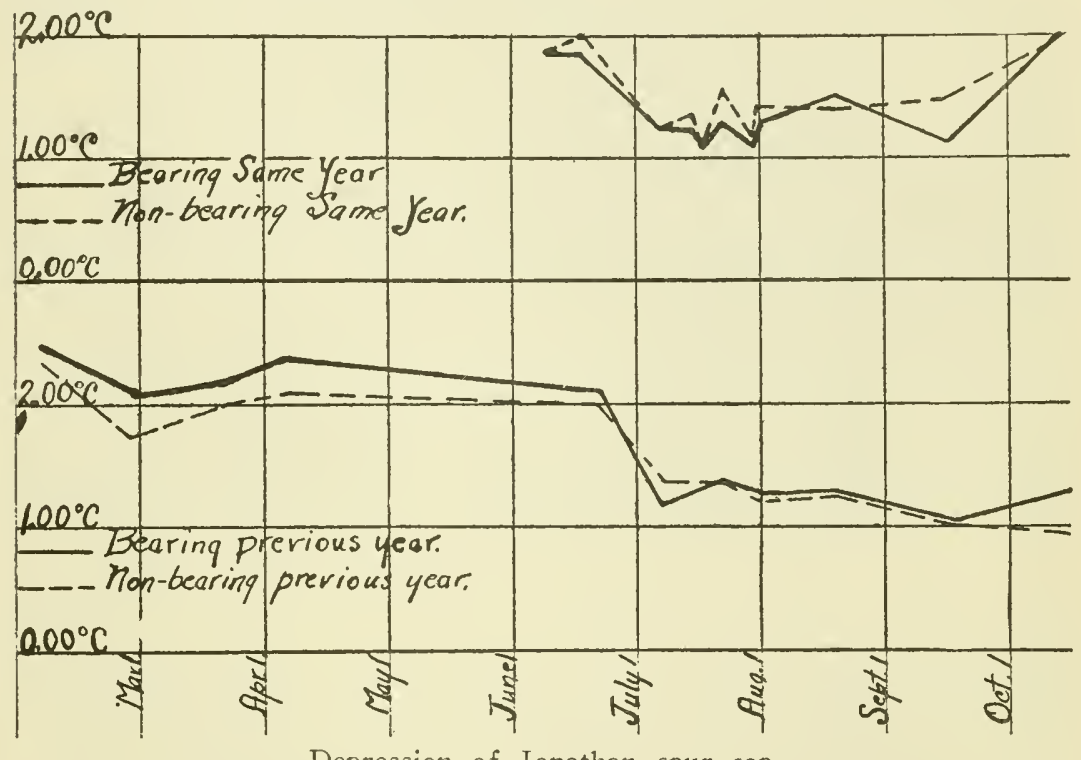

Depression of Jonathan spur sap

Marked seasonal variations in the sap density are also observed. The greatest change comes in late June and early July, at which time there is a sudden drop in concentration. This is the season at which the fruit buds for the next year's crop are forming and this abrupt drop may be either the cause or an effect of this fruit bud formation. It is noticeable in both the bearing and non-bearing spurs.

Apparently there is little difference in the concentration of the spur sap which can be attributed directly to soil conditions. Spurs from trees grown in two widely varying soil types showed little variation in the depression of the sap. Also, altho all of the above determinations were made upon sap from a Jonathan tree, there seems to be little varietal variation in this respect as the later determinations show.

The observations noted above concerning the difference in sap density in fruiting and non-fruiting parts at once opens up the question as to whether this condition may not be due to a withdrawal of 
moisture from the spur by the ripening fruit or by the leaves-a deficiency which may not be altogether overcome by the following spring. Chandler ${ }^{25}$ has observed that toward the ripening period water may be drawn from the fruit to the leaves. There may also be a similar movement of moisture from the spur which would at once have its effect upon the concentration of the sap of the spur.

The above determinations are perhaps too meager to warrant any positive conclusions but they are given as being suggestive of the idea that perhaps after all the food supply is not so important as has been assumed by some writers.

Leaf sap taken from leaves on fruiting and non-fruiting spurs did not show so consistent a difference as sap from the spurs themselves. The variations in these depressions, as shown in Table 19 are so great that it seems unwise to suggest any possible explanation.

Table 19.-Depression of Leaf Sap From Bearing and Non-bearing Jonathan Fruit Spurs

\begin{tabular}{|c|c|c|c|c|}
\hline \multirow{2}{*}{ Date } & \multicolumn{4}{|c|}{ Fruiting Condition } \\
\hline & $\begin{array}{l}\text { Bearing } \\
1915\end{array}$ & $\begin{array}{l}\text { Non-bearing } \\
1915\end{array}$ & $\begin{array}{l}\text { Bearing } \\
1916\end{array}$ & $\begin{array}{l}\text { Non-bearing } \\
1916\end{array}$ \\
\hline $\begin{array}{l}\text { June } 21,1916 \\
\text { July } 15, \quad 1915\end{array}$ & $\begin{array}{c}\text { Degrees C. } \\
2.680 \\
1.510\end{array}$ & $\begin{array}{c}\text { Degrees C. } \\
2.690 \\
1.590\end{array}$ & $\begin{array}{c}\text { Degrees C. } \\
2.550\end{array}$ & $\begin{array}{c}\text { Degrees C. } \\
2.880\end{array}$ \\
\hline July 22,1916 & 1.970 & 1.980 & 2.035 & 2.015 \\
\hline August 1, 1916 & 1.605 & 1.890 & 1.510 & 2.100 \\
\hline August 17, 1916 & 2.340 & 2.205 & 2.540 & 2.290 \\
\hline September 15, 1916 ................ & 2.255 & 1.995 & 2.190 & 2.460 \\
\hline October 14, $1916 \quad \ldots \ldots \ldots . . . . . . . .$. & 1.995 & 1.945 & 2.260 & 2.110 \\
\hline
\end{tabular}

Table 20.-Depression of Spur Sap from Spurs Bearing 3, 2, 1, or no Fruits

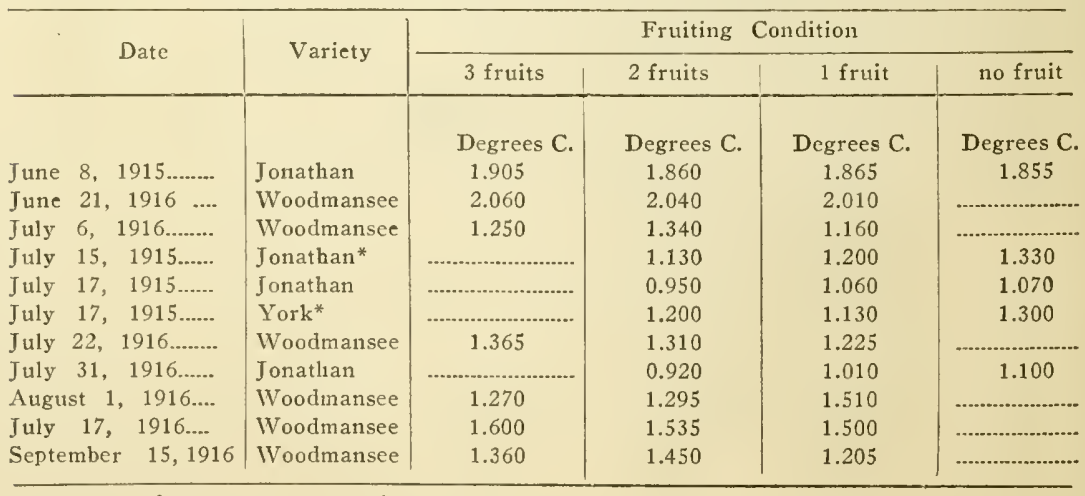

* Spurs from trees grown in loess soil. 


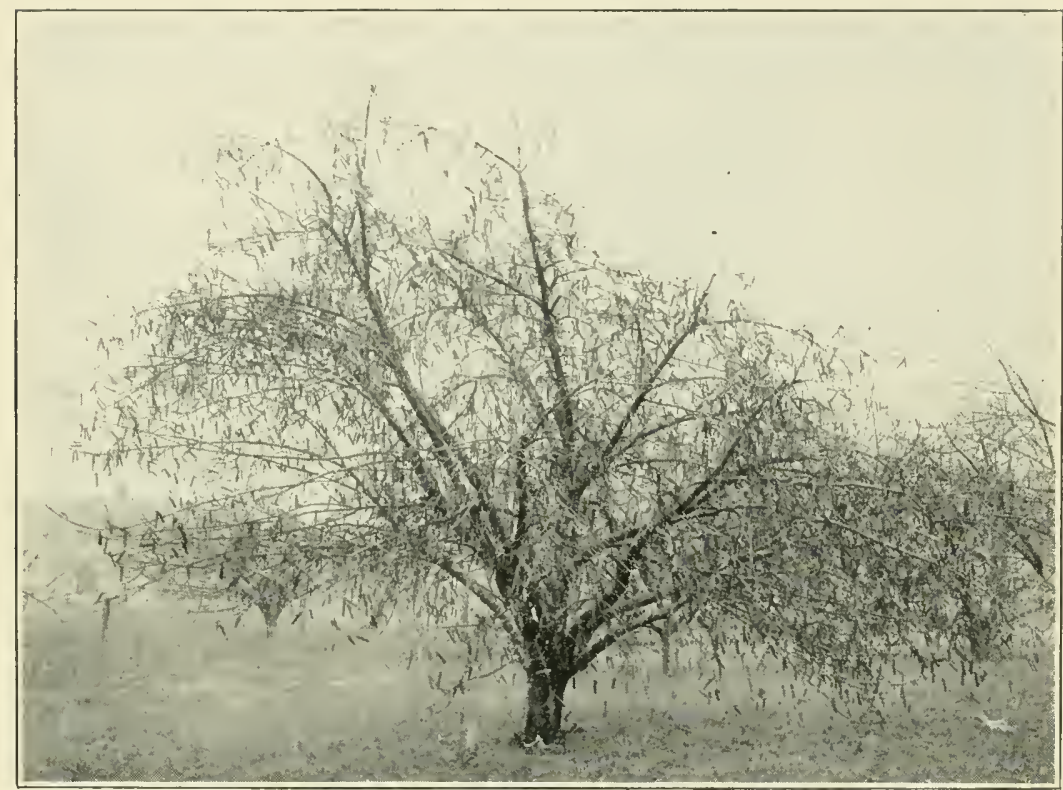

Fig. 1.-Gano apple tree on which some of the labeling work was done

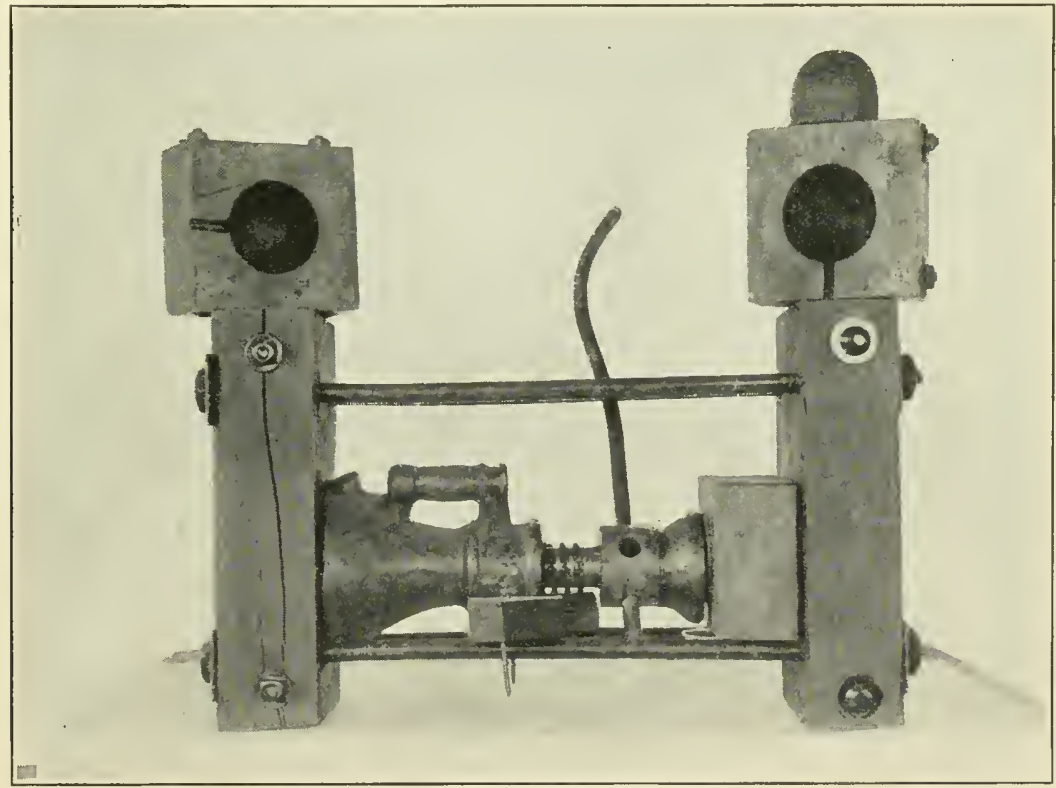

Fig.2.-Press and blocks by means of which the plant saps were expressed 


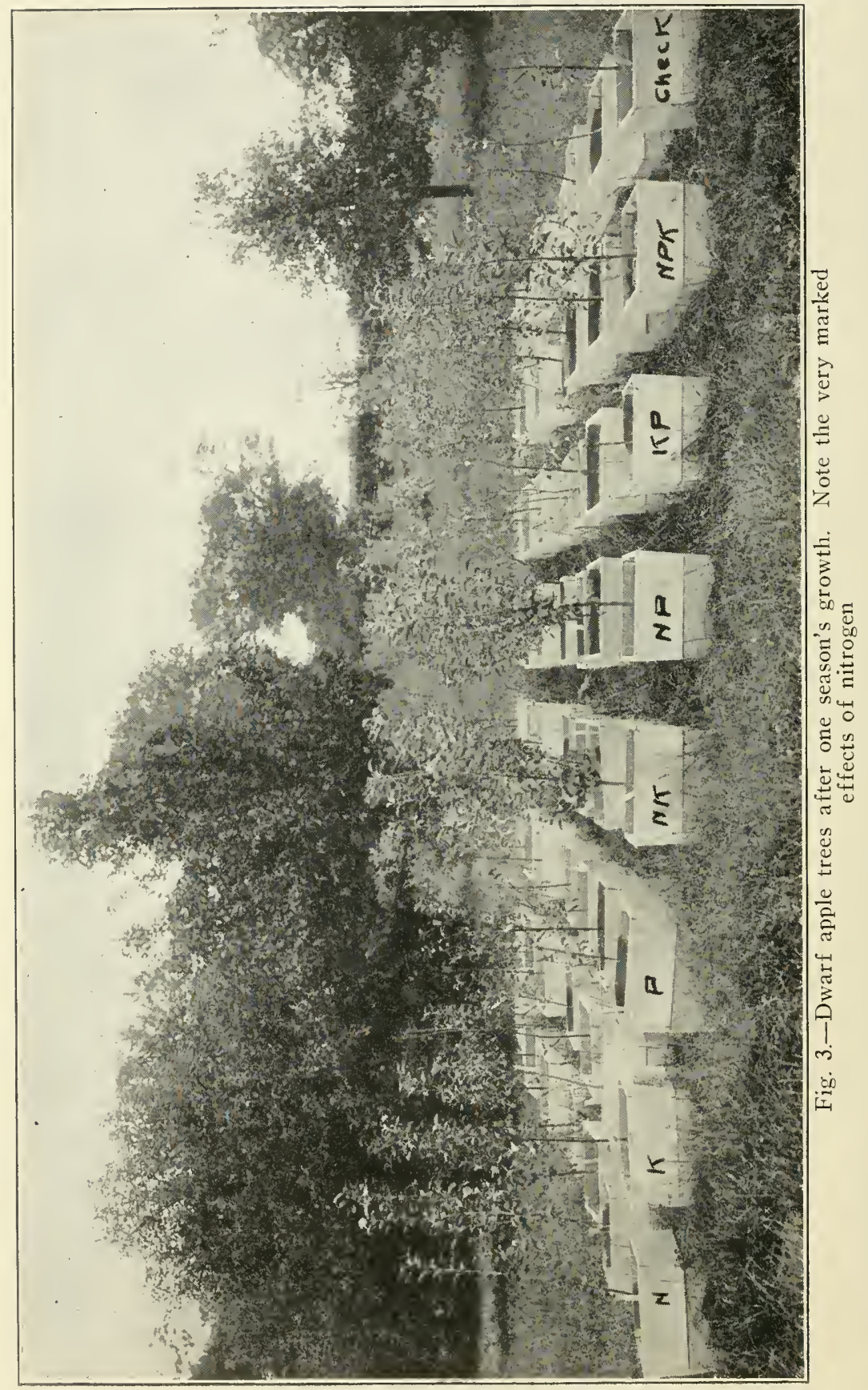


Also figures on the depression of spur sap, leaf sap, and fruit sap from spurs bearing three, two, and one fruits, are so inconsistent as to be of no assistance in helping to explain fruitfulness or nonfruitfulness. In general, it may be stated that it apparently makes little or no difference upon the concentration of the sap as to how many fruits a spur is maturing. The seasonal differences in the depression of the fruit spur sap are again brought out by Table 20 which checks very well with Table 18 in this respect.

Table 21.-Depression of Leaf Sap from Spurs Bearing 3, 2, or 1 Fruits

\begin{tabular}{|c|c|c|c|c|}
\hline \multirow{2}{*}{ Date } & \multirow{2}{*}{ Variety } & \multicolumn{3}{|c|}{ Fruiting Condition } \\
\hline & & 3 fruits & 2 fruits & 1 fruit \\
\hline 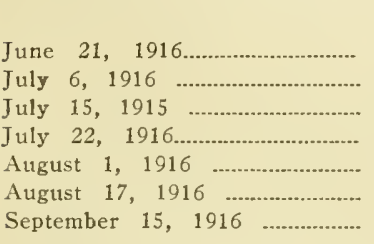 & $\begin{array}{l}\text { Woodmansee } \\
\text { Woodmansee } \\
\text { Jonathan } \\
\text { Woodmansee } \\
\text { Woodmansee } \\
\text { Woodmansee } \\
\text { Woodmansee }\end{array}$ & $\begin{array}{c}\text { Degrees C. } \\
2.660 \\
1.930 \\
1.940 \\
1.895 \\
2.650 \\
2.640\end{array}$ & $\begin{array}{c}\text { Degrees C. } \\
2.610 \\
1.790 \\
1.510 \\
1.830 \\
1.870 \\
2.550 \\
2.045\end{array}$ & $\begin{array}{c}\text { Degrees C. } \\
2.580 \\
1.830 \\
1.510 \\
2.035 \\
2.135 \\
2.540 \\
2.190\end{array}$ \\
\hline
\end{tabular}

Table 22.-Depression of Fruit Sap from Spurs Bearing 3, 2, or 1 Fruits

\begin{tabular}{|c|c|c|c|c|}
\hline \multirow{2}{*}{ Date } & \multirow{2}{*}{ Variety } & \multicolumn{3}{|c|}{ Fruiting Condition } \\
\hline & & 3 fruits & 2 fruits & 1 fruit \\
\hline June 8,1915 & Jonathan & $\begin{array}{c}\text { Degrees C. } \\
1.000\end{array}$ & $\begin{array}{c}\text { Degrees C. } \\
.960\end{array}$ & $\begin{array}{c}\text { Degrees C. } \\
.950\end{array}$ \\
\hline 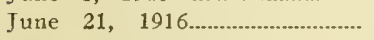 & Woodinansee & 1.880 & 2.040 & 1.900 \\
\hline July 6,1916 & Woodmansee & 1.180 & 1.040 & 1.040 \\
\hline July $22, \quad 1916$ & Woodmansee & 1.325 & 1.345 & 1.290 \\
\hline August 1, 1916 & Woodmansee & 1.325 & 1.330 & 1.320 \\
\hline August 17, 1916 & Woodmansee & 1.395 & 1.440 & 1.320 \\
\hline September 15, 1916 & Woodmansee & 1.415 & 1.435 & 1.355 \\
\hline
\end{tabular}

2. Chemical Determinations.-In order to get at the problem from a different angle and to compare especially the relative amounts of sugars and starch in the spurs, it was decided to employ some simple chemical methods. The method used in the sugar analysis was adapted very largely from the work of Davis and Daish ${ }^{33}$ and the starch determination was made in accordance with the directions in standard works on agricultural analysis. While these determinations possibly may not be all that might be desired from the chemical point of view, they are at least comparative and it is this connection that they are of value here. 
Considerable difficulty was encountered in securing satisfactory results, and, altho the work was begun early in 1917, several months had passed before it was felt that results of any reliability were obtained. The results given below were secured from spur material only, since the buds alone or the leaves could not be used satisfactorily.

The analyses were carried out according to the following plan:

1. Grind the material with a food chopper and then weigh out a 15gram sample.

2. Boil the sample for one hour in $500 \mathrm{cc}$. of 95 per cent alcohol to which had been added $5 \mathrm{cc}$. of ammonium hydroxide.

3. Filter and wash the residue with alcohol. Preserve the filtrate for the sugar determinations. Dry the residue for the starch determination.

4. Add $2 \mathrm{cc}$. of toluene to the filtrate and evaporate down to $40-50 \mathrm{cc}$. at $70^{\circ} \mathrm{C}$. Dilute to $250 \mathrm{cc}$. with water.

5. Precipitate the tannins in $200 \mathrm{cc}$. with basic lead acetate (sp. gr. 1.25), adding a small excess of this material. Make up to $250 \mathrm{cc}$. and filter.

6. To $200 \mathrm{cc}$. of this filtrate, add enough solid sodium carbonate to remove the excess basic lead acetate. Again make up to $250 \mathrm{cc}$. and filter.

7. To $25 \mathrm{cc}$. of this filtrate add a small amount of Fehling's Solution, boil for two minutes and then filter. Dry and weigh the cuprous oxide precipitate. This gives a measure of the amount of reducing sugar present.

8. To another $25 \mathrm{cc}$. sample add enough sulphuric acid to make it faintly acid to methyl orange. Then add 10 per cent by weight of citric acid crystals. Boil for ten minutes and then neutralize to phenolphthalein with sodium hydroxide. Add a sufficient quantity of Fehling's Solution to precipitate the total sugars as cuprous oxide. Filter, dry and weigh the precipitate.

9. Two and one-half grams of the residue from procedure No. 3 are placed in a flask with $200 \mathrm{cc}$. of water and $20 \mathrm{cc}$. of hydrochloric acid (sp. gr. 1.125). It is then boiled in a reflux condenser for two and one-half hours. One cc. of toluene is added after it cools.

10. Nearly neutralize with sodium hydroxide, using phenolphthalein as an indicator. Dilute to $250 \mathrm{cc}$.

11. Add Fehling's Solution to $25 \mathrm{cc}$, boil for two minutes, then dry and weigh the cuprous oxide precipitate. This indicates the amount of starch present. Pentoses and pentosans are also included.

The results secured are given in Table 23. No attempt has been made to calculate the actual percentage of sugars or starch present. The figures represent only the weight of cuprous oxide present in the aliquots indicated. All determinations were made upon the spurs of a Yellow Transparent tree. This variety was selected because of the accuracy with which the past performance of the spurs could be determined. 
Table 23.-Sugar and Starch Content of Yellow Transparent Fruit Spurs

\begin{tabular}{|c|c|c|c|c|}
\hline \multirow{2}{*}{ Date of Determination } & \multirow[b]{2}{*}{$\begin{array}{l}\text { Condition } \\
\text { of Spur }\end{array}$} & \multicolumn{2}{|c|}{ Weight of Cuprous Oxid } & Representing \\
\hline & & $\begin{array}{l}\text { Reducing } \\
\text { Sugar }\end{array}$ & $\begin{array}{l}\text { Total } \\
\text { Sugar }\end{array}$ & Starch \\
\hline \multirow{2}{*}{ October 22, 1917} & Bearing & .0153 & .0447 & .1861 \\
\hline & Non-bearing & .0191 & .0502 & .1815 \\
\hline \multirow[t]{2}{*}{ November 3, 1917} & Bearing & .0167 & .0530 & .1605 \\
\hline & Non-bearing & .0215 & .0488 & .1730 \\
\hline \multirow[t]{2}{*}{ November 17, 1917} & Bearing & $.0720^{*}$ & .0760 & .1569 \\
\hline & Non-bearing & .0150 & .0780 & .1560 \\
\hline \multirow[t]{2}{*}{ December 1, 1917} & Bearing & .0594 & .0800 & .1336 \\
\hline & Non-bearing & .0615 & .0690 & .0990 \\
\hline \multirow[t]{2}{*}{ December 19, 1917} & Bearing & .0305 & .0727 & .1332 \\
\hline & Non-bearing & .0477 & .0877 & .1477 \\
\hline \multirow{2}{*}{ January 3,1918} & Bearing & .0300 & .0700 & .1500 \\
\hline & Non-bearing & .0384 & .0800 & .1500 \\
\hline \multirow{2}{*}{ January 24, 1918} & Bearing & .0255 & .0530 & .1395 \\
\hline & Non-bearing & .0520 & .0965 & .0915 \\
\hline \multirow{2}{*}{ February 11, 1918} & Bearing & .0335 & .0780 & .1145 \\
\hline & Non-bearing & .0325 & .0750 & .1325 \\
\hline \multirow{2}{*}{ March 6, 1918} & Bearing & .0320 & .0855 & .1685 \\
\hline & Non-bearing & .0400 & .1000 & .1585 \\
\hline \multirow[t]{2}{*}{ March $20, \quad 1918 \ldots \ldots$} & Bearing & .0225 & .0740 & .1355 \\
\hline & Non-bearing & .0180 & .0500 & .0975 \\
\hline \multirow{2}{*}{ April 3, 1918} & Bearing & .0170 & .0325 & .1505 \\
\hline & Non-bearing & .0275 & .0540 & .1505 \\
\hline
\end{tabular}

"It is very probable that a portion of the non-reducing sugar is also included in this determination.

The number of determinations is small and the series incomplete in that there are no figures available for the important summer months preceding and during the time of fruit bud formation. Positive conclusions probably should not be formulated but the data are at least suggestive. It will be noticed that in a majority of the cases there seems to be a slightly greater amount of sugar, both reducing and total, in the non-bearing spurs. The starch content of the nonbearing spurs, however, does not average quite so high as in the bearing spurs but there is considerable variation in these results. The amount of starch apparently decreases somewhat, in both kinds of spurs, as the growing season approaches, while the amount of sugars increases.

Judging from these few determinations, some emphasis is given to the theory that the non-bearing spurs are able to lay up a greater amount of reserves than spurs which are maturing fruits. When compared with the total amount of reserves, however, this excess is very small. These results do not agree altogether with those secured from the freezing point determinations. The latter, however, gave a 
measure of soluble materials only. If the conclusion reached by Magness ${ }^{89}$, that reserves are stored near the point of synthesis, is a true one, then it would seem that the non-bearing spur accumulates only a slightly greater reserve supply than the fruiting spur. This difference, however, may be sufficient to account for the lack of fruit bud formation on such a large percentage of bearing branches.

\section{NUMBER OF LEAVES AND LEAF AREA OF FRUIT SPURS}

General observation long ago led to the conclusion tlat spurs maturing fruits had a smaller leaf area than adjacent spurs having no fruit upon them. In order to secure some definite idea as to the degree of this difference, some counts and measurements of the leaves on fruit spurs have been taken.

Counts made in 1915 gave the following figures concerning the number of leaves on the spurs. Several varieties were used, the number of spurs taken being large enough to be representative of the tree as a whole. In every case, as will be seen from Table 24, the non-bearing spur has the greater number of leaves, when averages are taken.

Table 24.-Number of Leaves on Bearing and Non-bearing Fruit Spurs

\begin{tabular}{|c|c|c|c|}
\hline & \multirow[t]{2}{*}{ Variety } & \multicolumn{2}{|c|}{$\begin{array}{l}\text { Average Number of Leaves } \\
\text { on Each Spur }\end{array}$} \\
\hline & & Bearing & Non-bearing \\
\hline Ben Dav & 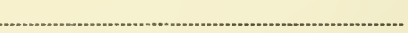 & 8.70 & 8.66 \\
\hline Jonathan & 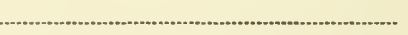 & 7.98 & 9.14 \\
\hline Ingram & 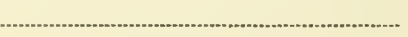 & 9.38 & 9.85 \\
\hline Minkler & . & 8.32 & 8.46 \\
\hline
\end{tabular}

In the next two seasons further counts and also some measurements were made, the leaf area being determined by the use of a polar planimeter. A summary of these results is given in Table 25. These data represent the figures secured from the measurements of more than two hundred and fifty spurs and hence may be taken as representative. It will be noted that from the average total leaf surface of the spur and the average number of leaves, the average size of the individual leaf has been calculated.

To give some idea of the range of variation found in both the number of leaves on a single spur and their total area, the figures on a few spurs taken at randon from Jonathan and Woodmansee trees are also given. (Tables 26 and 27.) 
Table 25.-Average Number of Leaves and Amount of Leaf Surface on Bearing and Non-bearing Spurs

\begin{tabular}{|c|c|c|c|c|c|c|}
\hline \multirow{2}{*}{ Variety } & \multicolumn{3}{|c|}{ Bearing Spurs } & \multicolumn{3}{|c|}{ Non-bearing Spurs } \\
\hline & $\begin{array}{l}\text { No of } \\
\text { Leaves }\end{array}$ & $\begin{array}{l}\text { Total } \\
\text { area }\end{array}$ & $\begin{array}{l}\text { Av. Leaf } \\
\text { Size }\end{array}$ & $\begin{array}{l}\text { No of } \\
\text { Leaves }\end{array}$ & $\begin{array}{l}\text { Total } \\
\text { area }\end{array}$ & $\begin{array}{l}\text { Av. Leaf } \\
\text { Size }\end{array}$ \\
\hline Doctor ..................... & 6.10 & $\begin{array}{l}\text { sq. in. } \\
13.72\end{array}$ & $\begin{array}{l}\text { sq. in. } \\
2.25\end{array}$ & 7.40 & $\begin{array}{c}\text { sq. in. } \\
20.80\end{array}$ & $\begin{array}{l}\text { sq. in. } \\
2.81\end{array}$ \\
\hline Summer Colville & 4.36 & 15.67 & 3.59 & 5.75 & 21.70 & 3.77 \\
\hline Eper & 6.16 & 9.86 & 1.57 & 8.15 & 13.66 & 1.67 \\
\hline Woodmansee .... & 4.38 & 6.83 & 1.55 & 6.16 & 13.67 & 2.21 \\
\hline Ben Davis ........... & 5.38 & 11.25 & 2.08 & 6.66 & 15.39 & 2.31 \\
\hline Missouri …........... & 5.36 & 6.96 & 1.29 & 7.64 & 9.89 & 1.29 \\
\hline Jonathan .............. & 6.65 & 10.83 & 1.62 & 8.41 & 14.58 & 1.73 \\
\hline
\end{tabular}

Table 26.-Numier ani Size or Leaves on Bearing and Non-bearing Jonathan Fruit Spurs

\begin{tabular}{|c|c|c|c|c|c|}
\hline \multicolumn{3}{|c|}{ Bearing } & \multicolumn{3}{|c|}{ Non-bearing } \\
\hline Spur No. & $\begin{array}{l}\text { No. of } \\
\text { Leaves }\end{array}$ & $\begin{array}{l}\text { Total } \\
\text { Leaf } \\
\text { Area }\end{array}$ & Spur No. & $\begin{array}{l}\text { No. of } \\
\text { Leaves }\end{array}$ & $\begin{array}{l}\text { Total } \\
\text { Leaf } \\
\text { Area }\end{array}$ \\
\hline 1 & 7 & $\begin{array}{l}\text { sq. in. } \\
15.76\end{array}$ & 1............. & 5 & $\begin{array}{r}\text { sq. in } \\
9.49\end{array}$ \\
\hline 2 & 7 & 9.69 & $2 \ldots \ldots$ & 8 & 12.30 \\
\hline $3 \ldots$ & 10 & 17.53 & 3.................. & 6 & 10.40 \\
\hline $4 \quad \ldots \ldots$ & 9 & 12.48 & 4............... & 9 & 13.34 \\
\hline $5 \quad \ldots \ldots \ldots$ & 5 & 8.45 & 5.......... & 9 & 18.63 \\
\hline $6 \ldots \ldots$ & 6 & 13.19 & 6 & 11 & 28.40 \\
\hline 7 & 7 & 12.72 & 7................ & 8 & 18.64 \\
\hline 8 & 14 & 20.05 & 8............ & 9 & 18.01 \\
\hline 9 .............. & 2 & 4.28 & 9............. & 11 & 18.14 \\
\hline $10 \ldots \ldots$ & 6 & 12.78 & 10 & 7 & 12.15 \\
\hline
\end{tabular}

Table 27.-Number and Size of Leaves on Bearing and Non-bearing WoodMANSEE Fruit SpURS

\begin{tabular}{|c|c|c|c|c|c|}
\hline \multicolumn{3}{|c|}{ Bearing } & \multicolumn{3}{|c|}{ Non-bearing } \\
\hline Spur No. & $\begin{array}{l}\text { No. of } \\
\text { Leaves }\end{array}$ & $\begin{array}{l}\text { Total } \\
\text { Leaf } \\
\text { Area }\end{array}$ & Spur No. & $\begin{array}{l}\text { No. of } \\
\text { Leaves }\end{array}$ & $\begin{array}{l}\text { Total } \\
\text { Leaf } \\
\text { Area }\end{array}$ \\
\hline ................. & 5 & $\begin{array}{r}\text { sq. in } \\
8.40\end{array}$ & 1................. & 6 & $\begin{array}{r}\text { sq. in } \\
15.05\end{array}$ \\
\hline $2 \ldots \ldots$ & 4 & 5.41 & $2 \ldots \ldots \ldots . . . . .$. & 6 & 11.99 \\
\hline 3 …............... & 4 & 7.12 & 3.............. & 5 & 13.57 \\
\hline $4 \quad \ldots . . .-\ldots$ & 3 & 3.82 & 4................ & 5 & 11.22 \\
\hline 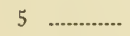 & 4 & 6.56 & 5................. & 4 & 9.23 \\
\hline 6 & 3 & 5.05 & 6................. & 5 & 11.61 \\
\hline 7 & 5 & 9.41 & 7............. & 6 & 8.80 \\
\hline $8 \ldots \ldots$ & 7 & 11.80 & $8 \ldots \ldots \ldots$ & 8 & 21.76 \\
\hline 9 .............. & 6 & 7.63 & 9................. & 9 & 22.20 \\
\hline 10 & 5 & 4.73 & $10 \ldots$ & 9 & 18.04 \\
\hline
\end{tabular}


In every case it is shown that non-bearing spurs have a larger number of leaves and a greater total leaf surface than non-fruiting spurs. When the average size of the individual leaf is computed, however, it is found that no very marked difference is present. It seems, therefore, that so far as the size of the individual leaf is concermed, it makes little difference whether it is upon a fruiting or non-fruiting spur. The greater total leaf area of the non-bearing part apparently comes almost wholly from the increased number of leaves which it develops.

The relative sizes of the individual leaves, and also the total leaf area, on bearing and non-bearing spurs is brought out clearly in Table 28. To get the figures given in this table, it is necessary only to divide the average individual leaf area of the non-bearing spur by that of the bearing spur. A similar operation gives the proportion between the total leaf area of non-bearing and bearing spurs.

Table 28.-Proportions Between Non-bearing and Bearing Spurs in Respect to (1) Area of Innividual Leaves, and (2) Total Leaf Area of the Spur

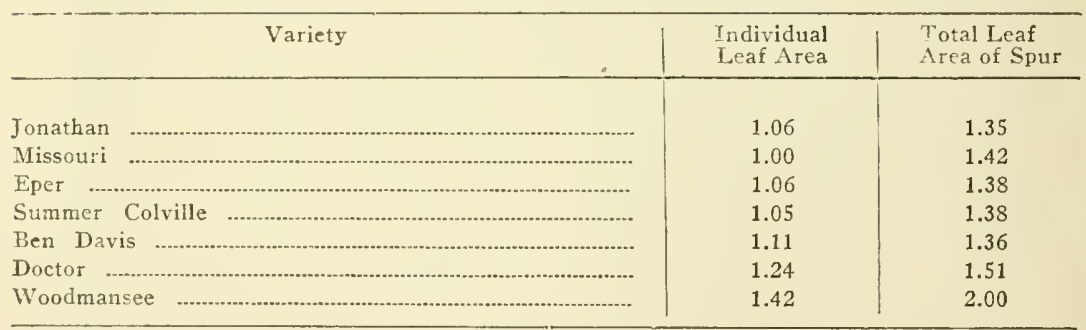

With the exception of Woodmansee and Doctor the varietal agreement in Table 28 is exceptionally good. Ben Davis also shows a slightly higher proportion between the sizes of individual leaves from non-bearing and bearing spurs than the more regular cropping varieties such as Missouri and Jonathan. There is just a suggestion here that this higher proportion may be correlated with alternation, for both the Ben Davis and Woodmansee are noted alternate bearers, the Woodmansee alternating probably more even than the Ben Davis. The other sorts have not fruited sufficiently long in this section for their bearing habits to be well known.

From these measurements, it is made clear that potentially, the non-fruiting spur has the much larger leaf surface from which to draw its supply of elaborated plant food. If this food is stored near the point where elaborated, then the non-fruiting spur should have the greater amount of such materials to draw upon in times of 
emergency. Reasoning from this alone, it is not difficult to see why fruit buds should form more often on non-fruiting than on fruiting spurs.

\section{EFFECTS OF GIRDLING UPON THE CONCENTRATION OF PLANT SAP}

Girdling has often been recommended as a very effective means of stimulating fruitfulness. With the purpose in view to determine the actual effects of girdling as revealed by the changes brought about in the plant sap concentration, some preliminary experiments were begun in the spring of 1915 . These first tests were conducted with nursery trees three years old, since it was thought the results obtained would be representative of what might occur on older trees. The number of available trees was so small, however, that a complete series of results could not be obtained at this time, so the work was continuted the following season.

The trees were girdled by removing a strip of bark approximately one inch in width from the trunk of the tree, the girdle usually being quite close to the ground. Trees were girdled at regular intervals thruout the spring and early summer and the subsequent effects of the girdling noted by determining the depression of the freezing point of the saps from time to tinc. These depressions were determined for all parts of the tree, leaves, twigs, trunk, and roots. In the case of woody tissues, the cortex only was ground up and pressed. The sap was expressed and the freezing point determined as described above in the case of the fruit spurs. The following tables present the data secured.

Table 29.-Effect of Girdling Uton the Depression of Trunk Sap 1-Bark from below girdle. 2-Bark from above girdle

\begin{tabular}{|c|c|c|c|c|c|c|c|c|c|}
\hline \multirow{2}{*}{\multicolumn{2}{|c|}{ Date of Girdling }} & \multicolumn{8}{|c|}{ Depression on Date Given, 1915} \\
\hline & & June 1 & J une $19 \mid$ & July 7 & July 28 & Aug. 18 & Sept.10 & Oct. 23 & Mov.2 \\
\hline \multirow{2}{*}{\multicolumn{2}{|c|}{ Check ... }} & 0.920 & 0.995 & 0.870 & 0.890 & 0.870 & 1.070 & 1.360 & 1.320 \\
\hline & …-..- 1 & & & & 0.790 & & & & \\
\hline April 27 & 2 & 1.320 & & & 1.310 & & ................ & & \\
\hline \multirow[t]{2}{*}{ May 29} & ... 1 & .............. & 0.765 & & 0.920 & …... & ....... & …......... & \\
\hline & 2 & $\cdots+\cdots$ & & & & & .............. & …….......... & \\
\hline June 9 & $\begin{array}{l}1 \\
2\end{array}$ & $\cdots+\cdots-\ldots$ & 0.785 & & 0.830 & 0.660 & & ... & \\
\hline \multirow[t]{2}{*}{ July 1} & $\begin{array}{l}2 \\
1\end{array}$ & …......... & 1.0 & & $\begin{array}{l}1.190 \\
0.780\end{array}$ & & 0.6 & ......... & \\
\hline & 2 & 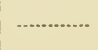 & $\cdots+\cdots$ & 1.030 & 1.080 & 1.2 & & & \\
\hline July 15 & $\begin{array}{r}1 \\
2\end{array}$ & $\cdots+\cdots$ & $\cdots \cdots \cdots$ & 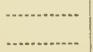 & $\begin{array}{l}0.820 \\
0.910\end{array}$ & $\begin{array}{l}0.6 \\
1.0\end{array}$ & & & \\
\hline \multirow[t]{2}{*}{ July 31} & 1 & .............. & (n)..... & & ............. & 0.81 & 0.91 & & 0.7 \\
\hline & 2 & ........... & .......... & & $\ldots+\ldots . . .$. & 1.000 & 1.220 & 1.450 & 1.8 \\
\hline \multirow[t]{2}{*}{ Augu } & .............. & $\cdots$ & ‥-... & -........... & ……...... & (............. & 0.930 & 0.830 & 0.820 \\
\hline & .............. 1 & ….......... & …… & ……... & …-1-. & ……...... & 1.130 & $\begin{array}{l}1.550 \\
0.930\end{array}$ & $\begin{array}{l}1.740 \\
0.890\end{array}$ \\
\hline September 8 & 2 & .............. & ................. & …‥-1 & ……-... & .....-1- & ............... & 1.380 & 1.700 \\
\hline
\end{tabular}


Table 30.-Effect of Girdling Upon the Depression of Twig Sap

\begin{tabular}{|c|c|c|c|c|c|c|}
\hline \multirow{2}{*}{ Date of Girdling } & \multicolumn{6}{|c|}{ Depression on Date Given, 1915} \\
\hline & June 3 & June 21 & June 24 & July 7 & July 28 & Aug. 18 \\
\hline 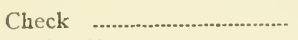 & 1.240 & 1.200 & 1.200 & 1.090 & 0.870 & 1.020 \\
\hline April $27 \quad \ldots$ & 1.450 & 1.380 & (n)................. & 1.370 & 1.050 & (n)................... \\
\hline May 29 & & (n)................. & 1.450 & 1.300 & (n)................. & (n)............... \\
\hline June 9 & .................... & ................... & 1.410 & 1.250 & 1.090 & 0.870 \\
\hline July 1 & (................... & (n...................... & (................... & 1.170 & 1.170 & 1.210 \\
\hline July 15 & ................. & .................. & (................... & ................. & 1.110 & 1.230 \\
\hline July 31 & & ................. & ................. & ................... & .................... & 1.150 \\
\hline
\end{tabular}

Table 31.-Effect of Girdling Upon the Depression of Leaf Sap

\begin{tabular}{|c|c|c|c|c|c|c|c|}
\hline \multirow{2}{*}{ Date of Girdling } & \multicolumn{7}{|c|}{ Depression on Date Given, 1915} \\
\hline & June 3 & June 21 & July 7 & July 28 & Aug. 18 & Sept. 10 & Oct. 23 \\
\hline Check ............. & 1.410 & 1.950 & 1.900 & 1.630 & 1.400 & 2.010 & 2.570 \\
\hline April $27 \quad \ldots . . .$. & 2.050 & 2.250 & 2.420 & 2.360 & 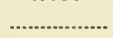 & 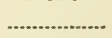 & ....................... \\
\hline May 29 ......... & ..................... & 1.970 & 2.210 & 2.710 & & & \\
\hline June 9 & & 2.270 & 2.270 & 2.0 & 1.825 & & \\
\hline July 1 & ..................... & 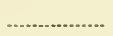 & 2.140 & 1.970 & 2.210 & 2.130 & \\
\hline July 15 & & .......................... & ...................... & 1.940 & 1.860 & 1.970 & 2.800 \\
\hline July 31 & & & & (.................... & 1.780 & 1.820 & ...................... \\
\hline August $18 \quad \ldots$ & & (............... & - n & 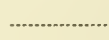 & - n & 2.000 & 2.740 \\
\hline September 8 & & 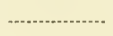 & ...................... & 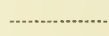 & 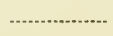 & ........................ & 2.770 \\
\hline
\end{tabular}

Table 32.-Effect of Girdling Upon the Depression of Root Sap

\begin{tabular}{|c|c|c|c|c|c|c|c|}
\hline \multirow{2}{*}{ Date of Girdling } & \multicolumn{7}{|c|}{ Depression on Date Given, 1915} \\
\hline & June 21 & July 7 & July 28 & Aug. 19 & Sept. 10 & Nov. 5 & Nov. 22 \\
\hline Check ............ & 0.830 & 0.740 & 0.750 & 0.900 & 0.960 & 1.120 & 1.310 \\
\hline April 27 & 0.640 & 0.720 & 0.500 & & ....................... & ...................... & ..................... \\
\hline May $29 \quad \ldots \ldots . .$. & 0.680 & 0.570 & 0.610 & & & & \\
\hline June 9 & 0.690 & 0.550 & 0.630 & 0.800 & & .......... & \\
\hline July 1 & (..................... & 0.670 & 0.590 & 0.620 & 0.620 & & ....................... \\
\hline July $15 \quad \ldots . .$. & (.................... & ........................ & 0.640 & 0.540 & 0.975 & 0.890 & 1.090 \\
\hline July 31 & ..................... & ..................... & .................. & 0.700 & 0.730 & 0.720 & 0.650 \\
\hline August $18 \ldots . .$. & (n)..................... & & ……............. & (.................... & 0.780 & 0.700 & 0.790 \\
\hline September $8 . .$. & (..................... & (n.............. & ..................... & ................... & ...................... & 0.660 & 0.940 \\
\hline
\end{tabular}

A study of the preceding tables shows rather distinctly the following features. In the case of sap from the trunk of the tree, the girdled trees had the highest concentration above the girdle and the lowest below, with the check tree intermediate. These differences were discernible almost immediately after the girdle was made, and remained consistent. However, there is evidence pointing to the conclusion that these differences grow less as the season advances. When it is considered that in many cases the girdled area had been partly 
or almost entirely healed over by cambium development, this evidence is not surprising.

Twig sap from girdled trees is slightly more concentrated than that from normal trees but the difference is hardly so great as those noted above for trunk sap. Leaf sap shows more variation than either the twig or trunk sap but in a majority of the determinations the leaf sap from the girdled tree possessed the greater stuply of plant food as evidenced by its lower freezing point.

Root sap differs from the other portions of the tree by having a sap of the lower concentration in the case of girdled trees.

From the foregoing it is readily seen that the sap of all parts above the girdle has an increased sap density, and that of all parts below, a decreased sap density, when compared with sap from corresponding parts of similar ungirdled trees.

Nursery trees were also used for the 1916 work, but these were four or five years old,-in fact, they were sufficiently old that some had begun to produce a small amount of fruit. The scope was broadened so that in addition to the root and trunk sap, leaf sap was secured from new growth, both above and below the girdle, and from the one-year-old spurs, potential fruiting wood, which the trees had developed. The twig sap determinations were made upon sap from the new growth both above and below the girdle and also from the one-year-old twigs.

Examinations of the trees had revealed that several specimens had been either totally or partly girdled by rabbits the previous winter (1915-16). It was decided to include these along with the newly girdled trees, to see just what effect such injury might have upon the plant sap.

The trees were girdled in a manner similar to that employed upon the earlier ones and the determinations made as noted above. The results follow:

Table 33.-Effect of Girdling Upon the Freezing Point

Depression of trunk sap above the girdle

\begin{tabular}{|c|c|c|c|c|c|c|}
\hline \multirow{2}{*}{ Date of Girdling } & \multicolumn{3}{|c|}{ Depression on } & \multirow{2}{*}{$\begin{array}{c}\text { Date Given, } \\
\text { July } 27\end{array}$} & \multicolumn{2}{|l|}{1916} \\
\hline & June 12 & June 26 & July 12 & & Aug. 7 & Aug. 24 \\
\hline Check & 1.220 & 1.510 & 1.085 & 1.255 & 2.145 & 2.695 \\
\hline $\begin{array}{c}\text { Partly girdled by rabbits } \\
1916-17\end{array}$ & 1.430 & 1.340 & 1.280 & 2.025 & 2.255 & 1.715 \\
\hline Entirely girdled by rabbits & & & & & & \\
\hline $1916-17$ & 1.000 & 1.660 & 1.395 & 1.765 & 2.250 & 1.925 \\
\hline June 12 & (.................... & 1.460 & 1.110 & 1.760 & 2.195 & 2.720 \\
\hline June 26 & (n.................... & (n)................... & 1.020 & 1.245 & 1.675 & 2.070 \\
\hline July 11 & (n)............... & (n................... & (n)....................... & 1.250 & 1.665 & 2.605 \\
\hline July 24 & & (n)................... & (n)...................... & (n)................. & 2.100 & 2.240 \\
\hline 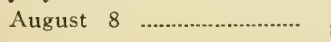 & & …............... & (n)........................ & n................... & (n................... & 1.695 \\
\hline
\end{tabular}


Table 34.-Effect of Girdling Upon the Freezing Point Depression of twig sap

\begin{tabular}{|c|c|c|c|c|c|c|c|}
\hline \multirow{2}{*}{\multicolumn{2}{|c|}{ Date of Girdling }} & \multicolumn{6}{|c|}{ Depression on Date Given } \\
\hline & & June 12 & June 26 & July 12 & July 24 & Aug. 7 & Aug. 24 \\
\hline \multirow[t]{3}{*}{ Check-not girdled........ } & 1 & 1.930 & 1.260 & 1.130 & 1.085 & 1.720 & 1.495 \\
\hline & 2 & 2.590 & 1.510 & 1.605 & 1.480 & 1.780 & 1.900 \\
\hline & 3 & 2.000 & 1.800 & 1.640 & 2.200 & 2.210 & 2.665 \\
\hline \multicolumn{8}{|l|}{ Partly girdled by rabbits } \\
\hline \multirow{3}{*}{ winter of 1916-17..... } & 1 & 1.560 & 1.440 & 1.030 & 1.585 & 1.445 & 1.405 \\
\hline & 2 & 2.500 & 1.650 & 1.475 & 1.945 & 1.890 & 1.745 \\
\hline & 3 & 2.540 & 2.030 & 1.375 & 2.260 & 2.330 & 2.355 \\
\hline \multicolumn{8}{|l|}{ Entirely girdled by rabbits } \\
\hline \multirow{3}{*}{\multicolumn{2}{|c|}{ winter of $1916-17 \ldots \ldots .1$}} & 1.150 & 1.210 & 0.900 & (n)................ & 1.450 & \\
\hline & & 2.270 & 2.110 & 1.425 & 2.315 & 2.125 & 1.745 \\
\hline & & 2.100 & 1.410 & 1.540 & 1.715 & 1.780 & 2.370 \\
\hline \multirow{3}{*}{ June 12} & 1 & (n)................... & 1.060 & 0.735 & 1.425 & 1.810 & 1.920 \\
\hline & 2 & - & 2.230 & 1.240 & 1.515 & 1.965 & 1.985 \\
\hline & 3 & (............ & 2.760 & 1.455 & 2.175 & 2.845 & 3.430 \\
\hline \multirow{3}{*}{ June 26} & 1 & (n)................. & (....................... & 0.995 & (n).............. & 1.395 & 1.185 \\
\hline & 2 & (n)................... & (.................. & 1.475 & 1.735 & 1.585 & 1.470 \\
\hline & 3 & (n)............ & (n)............... & 1.895 & 1.620 & 2.035 & 1.520 \\
\hline \multirow[t]{3}{*}{ July 11} & 1 & (2)................. & (................- & (n)........................ & 1.010 & 1.790 & 1.405 \\
\hline & 2 & (.................. & 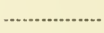 & (n)................ & 1.655 & 2.170 & 1.610 \\
\hline & 3 & 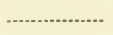 & (.................. & (n)............. & 1.795 & 3.100 & 2.460 \\
\hline \multirow[t]{3}{*}{ July 24} & 1 & ..................... & ................... & .................... & .................. & 1.285 & 1.300 \\
\hline & 2 & .............. & .............. & . & . & 2.365 & 1.605 \\
\hline & 3 & ........................ & ..................... & ...................... & ........................ & 2.490 & 2.280 \\
\hline \multirow[t]{3}{*}{ August 8} & 1 & ...................... & ........................ & ...................... & .................... & .................... & 1.195 \\
\hline & 2 & ............ & - & - & ..................... & .......... & 1.695 \\
\hline & 3 & ........ & ......................... & ........ & ....................... & -................... & 2.790 \\
\hline
\end{tabular}

NOTE: 1-New growth below the girdle. 2-New growth above the girdle. 3-One year old twigs or spurs.

These tables may be very briefly summed up by repeating the general conclusions reached from the earlier work, which are that the parts above the girdle show a greater density, and the parts below, a lesser concentration of plant sap, than is found to be the case with check trees. The trees girdled by rabbits exhibit a behavior very similar to the other girdled trees except that the sap from the partly girdled tree is more variable. This is probably to be expected since varying amounts of the cambium had been removed from these trees. Sap from corresponding parts above and below the girdle on the same tree shows the higher concentration, with few exceptions, in the parts above the girdle. As a rule, the sap of one-year-old twigs has a greater density than sap from twigs representing the current year's growth. Leaf sap from these parts stands in the same relation as the twig sap.

That girdling does lead to increased fruitfulness is a matter of common knowledge. The foregoing data furnish one definite reason 
Table 35.-Effect of Girdling Upon the Freezing Point Depression of leaf sap

\begin{tabular}{|c|c|c|c|c|c|c|}
\hline \multirow{2}{*}{ Date of Girdling } & \multicolumn{6}{|c|}{ Depression on Date Given } \\
\hline & June 12 & June 26 & July 12 & July 24 & Aug. 7 & Aug. 24 \\
\hline \multirow{3}{*}{ Check-not girdled ...... } & 2.940 & 1.710 & 1.915 & 2.265 & 2.240 & 3.010 \\
\hline & 2.730 & 1.910 & 2.360 & 2.555 & 2.615 & 3.570 \\
\hline & 2.530 & 2.750 & 2.275 & 2.435 & 2.430 & 3.540 \\
\hline \multicolumn{7}{|l|}{ Partly girdley by rabbits } \\
\hline \multirow{3}{*}{ winter of $1916-17 \ldots \ldots$} & 2.230 & 2.160 & 1.780 & 2.310 & 2.325 & 2.420 \\
\hline & 2.580 & 2.140 & 2.035 & 2.675 & 2.790 & 2.660 \\
\hline & 2.870 & 2.070 & 2.005 & 2.505 & 2.460 & 3.100 \\
\hline \multicolumn{7}{|l|}{ Partly girdled by rabbits } \\
\hline \multirow{3}{*}{ winter of $1916-17 \ldots \ldots$} & 1.490 & 2.020 & 1.515 & ............... & 2.065 & 2.370 \\
\hline & 3.150 & 2.760 & 2.390 & 2.825 & 2.970 & 2.985 \\
\hline & 2.800 & 2.610 & 2.215 & 3.015 & 2.925 & 2.945 \\
\hline \multirow[t]{3}{*}{ June 12} & (n................... & 1.610 & (n................... & 1.970 & 2.545 & 3.440 \\
\hline & (n................. & 2.880 & 2.300 & 2.725 & 2.995 & 3.820 \\
\hline & (.......... & 2.810 & 2.290 & 2.800 & 2.915 & 3.070 \\
\hline \multirow[t]{3}{*}{ June 26} & & .............. & (................... & 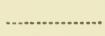 & 2.130 & 2.335 \\
\hline & (n..................... & (n..................... & 2.545 & 2.530 & 2.855 & 3.010 \\
\hline & & (n)................. & 2.550 & 2.445 & 2.880 & 2.980 \\
\hline \multirow[t]{3}{*}{ July 11} & & (.................... & (n......................... & 1.975 & 2.145 & 2.955 \\
\hline & (n).................... & (n) & (n).................... & 2.555 & 3.015 & 3.655 \\
\hline & & (n................... & (n...................... & 2.705 & 3.175 & 3.785 \\
\hline \multirow[t]{3}{*}{ July 24} & (n....... & (n)................... & 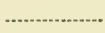 & (n................. & 1.990 & 2.230 \\
\hline & ......... & (..................... & (n)...................... & (n)......................... & 2.910 & 3.010 \\
\hline & & & .......... & (n).................. & 2.820 & 3.260 \\
\hline \multirow[t]{3}{*}{ August 8} & & (n)................... & (n).................. & ................... & ........................ & 2.560 \\
\hline & .................. & .................... & ...................... & ................ & . & 3.570 \\
\hline & ................ & 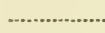 & . & ................... & . & 3.590 \\
\hline
\end{tabular}

NOTE: 1-From new growth below the girdle. 2-From new growth above the girdle. 3-From one year old branches or spurs.

Table 36.--Effect of Girdling Upon the Freezing Point

Depression of root sap

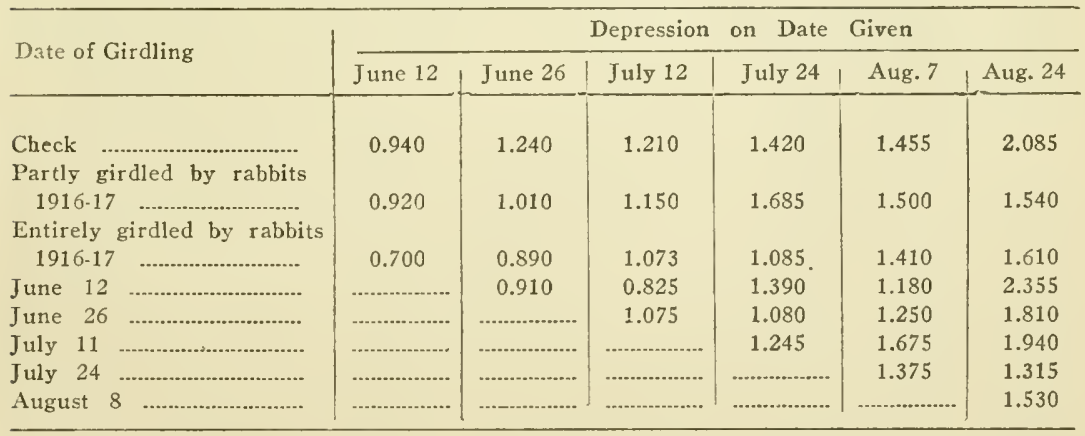

why this phenomenon occurs, since it is very evident that girdling does cause an increased supply of food materials to accumulate in the parts above the girdle. It is conceivable that such an accumula- 
tion of reserves should result in the formation of a greater number of fruit buds. The data also indicate that girdling in early summer is likely to be most efficacious in promoting fruit bud formation since the greatest differences in concentration are evident if the girdling is done at that time.

This conclusion does not agree altogether with the data secured from the fruit spur studies in which it was found that the differences in the amount of food reserves present in bearing and nonbearing parts were very slight. However, it will be noted that girdling, severe as it is, did not cause a marked difference in the concentration of the sap of the outermost parts of the tree. The greatest effect is to be observed on the trunk sap but this difference lessens as the distance from the girdle increases. The leaves and twigs at the periphery of the tree where the fruit buds are formed do not show such great variation. This may furnish an explanation for the slight difference found in the case of the bearing and non-bearing spurs. It is entirely possible that the reserves which are responsible for fruit bud formation are brought from some point beyond the spur itself, and hence, data based upon spur sap alone may not indicate the difference which actually exists in the food supply.

\section{THE EFFECT OF FERTILIZERS UPON FRUITFULNESS}

The following experiment, begun at the Missouri Experiment Station in 1914, was designed to show the specific effects of chemical fertilizers, applied either singly or in combination, upon the fruitfulness of apples. The results are as yet incomplete, since the trees are just beginning to show some of the effects of the fertilizers. It is the plan to continue the work for several seasons, but a part of the data are of interest in connection with this investigation and for that reason are included here.

The plants used for this work were one-year-old Rome Beauty apple trees, budded upon Paradise stock. The trees were very uniform in size and appearance at the time of planting. They were set in wooden boxes $18 \times 18$ inches at the top, $16 \times 16$ inches at the bottom, and 16 inches in depth. One-half the number of boxes were filled with Missouri River sand and the other half with loess soil. The amount of sand used in each case was 75 kilograms, and of soil, 90 kilograms. Suitable samples showed that the soil contained 13.27 per cent of moisture while the sand held only 3.42 per cent.

It was thought that by planting the trees in the boxes, the effect of the fertilizers could be more readily distinguished, since there 
would not be so many outside factors to be taken into consideration. For similar reasons, it was thought advisable to use sand, a medium practically free of plant food, on one medium and loess soil, a soil type well suited to fruit trees generally, for the other. Both mechanical and chemical analyses were made of the sand and of the soil. These analyses in tabular form follow:

Table 37.-Chemical Analyses of Loess Sorl and Missouri River Sand*

\begin{tabular}{|c|c|c|}
\hline Material & $\begin{array}{l}\text { Per Cent in } \\
\text { Loess Soil }\end{array}$ & $\begin{array}{l}\text { Per Cent in } \\
\text { Sand }\end{array}$ \\
\hline Water** ............. & 1.740 & .110 \\
\hline 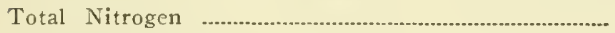 & .019 & .005 \\
\hline 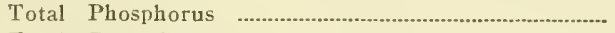 & .073 & .056 \\
\hline 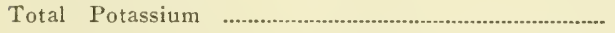 & 1.667 & 1.599 \\
\hline
\end{tabular}

*Analyses furnished by Agricultural Chemistry Department of Missouri Experiment Station.

** In air-dry material.

Table 38.-Mechanical Analyses of Loess Soll and Missouri River Sand

\begin{tabular}{|c|c|c|}
\hline Soil Particles & $\begin{array}{l}\text { Per Cent in } \\
\text { Loess Soil }\end{array}$ & $\begin{array}{l}\text { Per Cent in } \\
\text { Sand }\end{array}$ \\
\hline Fine gravel ............. & 0.00 & 6.59 \\
\hline 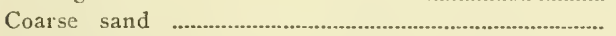 & 0.00 & 19.05 \\
\hline 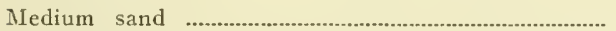 & 0.93 & 35.33 \\
\hline Fine sand & 45.79 & 35.31 \\
\hline Very fine sand & 33.81 & 0.13 \\
\hline Silt & 11.07 & 0.00 \\
\hline Clay & 8.42 & 3.47 \\
\hline
\end{tabular}

The fertilizers used have been sodium nitrate, acid phosphate, and potassium sulphate, in their common commercial forms. They were applied singly and in all possible combinations. Each plot contained eight trees, four in loess soil and four in sand. A check plot received no treatment at all. All fertilizer applications were made in the spring just as growth was beginning. The amounts used per tree were, sodium nitrate, 15 grams; acid phosphate, 30 grams; and potassium sulphate, 30 grams.

The trees lave remained exposed to outside conditions from the time of planting, except that during the winter the roots have been protected somewhat from the cold by filling the spaces between the boxes with sawdust and also covering the boxes with boards. Whenever necessary, water has been supplied during summer drouths. Figure 3 shows the trees in the second seasons's growth.

Data have been kept upon a great many different points, but the only phases of any particular interest here are (1) the number of 
potential fruiting parts developed and (2) the actual number of fruit buds formed. The number of fruiting parts was determined by counting the number of short branches, two inches or less in length, that had developed on the varions trees, and the number of fruit buds by counting the number of blossom clusters that opened. These figures are given in Tables 39 and 40.

Table 39.-Average Number of Potential Fruiting Parts Developed on TREes in Fertilizer EXPeriment

\begin{tabular}{|c|c|c|c|}
\hline \multirow{2}{*}{ Fertilizer } & \multirow{2}{*}{ Medium } & \multicolumn{2}{|c|}{ Year } \\
\hline & & 1916 & 1917 \\
\hline \multirow{3}{*}{$\mathrm{N}$} & Soil & 53 & 64 \\
\hline & Sand & 8 & 28 \\
\hline & Soil & 9 & 21 \\
\hline & Sand & 12 & 17 \\
\hline \multirow{2}{*}{$\mathrm{P}$} & Soil & 8 & 19 \\
\hline & $\begin{array}{l}\text { Sand } \\
\text { Soil }\end{array}$ & $\begin{array}{r}4 \\
31\end{array}$ & 18 \\
\hline KN & Sand & 9 & 33 \\
\hline \multirow[t]{2}{*}{ NP ... } & Soil & 49 & 52 \\
\hline & Sand & 2 & 35 \\
\hline \multirow[t]{2}{*}{ KP } & Soil & 8 & 15 \\
\hline & Sand & 5 & 15 \\
\hline NKP …......................... & $\begin{array}{l}\text { Sool } \\
\text { Sand }\end{array}$ & $\begin{array}{r}43 \\
6\end{array}$ & $\begin{array}{l}69 \\
22\end{array}$ \\
\hline \multirow[t]{2}{*}{ Check ............. } & Soil & 8 & 20 \\
\hline & Sand & 6 & 30 \\
\hline
\end{tabular}

NOTE: N-Sodium Nitrate. K-Potassium Sulphate. P-Acid Phosphate.

Table 40.-Total Number of Blossom Buds Produced on Trees in FertiLIZER EXPERIMENT

\begin{tabular}{|c|c|c|c|c|c|}
\hline \multirow{2}{*}{ Fertilizer } & \multirow{2}{*}{ Medium } & \multirow{2}{*}{ No. Trees } & \multicolumn{3}{|c|}{ Blossom Buds in } \\
\hline & & & 1916 & 1917 & 1918 \\
\hline \multirow[t]{2}{*}{$\mathrm{N}$} & Soil & 2 & $7^{\circ}$ & 45 & 22 \\
\hline & Sand & 4 & 0 & 0 & 83 \\
\hline \multirow[t]{2}{*}{$\mathrm{K}$} & Soil & 3 & 0 & 0 & 0 \\
\hline & Sand & 4 & 0 & 0 & 0 \\
\hline \multirow[t]{2}{*}{$\mathbf{P}$} & Soil & 3 & 0 & 0 & 0 \\
\hline & Sand & 4 & 0 & 0 & 0 \\
\hline \multirow[t]{2}{*}{ NK } & Soil & 4 & 11 & 29 & 287 \\
\hline & Sand & 4 & 2 & 8 & 241 \\
\hline \multirow[t]{2}{*}{ NP } & Soil & 4 & 8 & 8 & 117 \\
\hline & Sand & 4 & 1 & 27 & 139 \\
\hline \multirow[t]{2}{*}{ KP } & Soil & 3 & 0 & 0 & 0 \\
\hline & Sand & 3 & 0 & 0 & 0 \\
\hline \multirow[t]{2}{*}{ NKP } & Soil* & 4 & 37 & 124 & 306 \\
\hline & Sand & 4 & 2 & 1 & 107 \\
\hline \multirow[t]{2}{*}{ Check } & Soil & 4 & 0 & 0 & 2 \\
\hline & Sand & 4 & 0 & 0 & 6 \\
\hline
\end{tabular}

NOTE: N-Sodium Nitrate. K-Potassium Sulphate. P-Acid Phosphate.

* One tree in this lot had become girdled with a label wire and it alone produced 24 clusters in 1915. 
From these two tables, it is very evident that the application of nitrogen has been a very decisive factor in both the formation of fruiting parts and the development of bloom buds. Apparently the mediums used needed little or no potassium or phosphorous in this connection, for these elements gave really no increase over the check when applied either singly or in combination. It is only where the nitrogen was added that any effect is noted, this effect being nearly as great in the loess soil plots as in the sand plots.

\section{EFFECT OF THE TILLAGE SYSTEM UPON THE CON- CENTRATION OF SAP IN YOUNG APPLE TREES}

That the method of handling the soil and the kinds of plants used for intercropping a young orchard have considerable effect upon the subsequent bearing and behavior of apple trees is the conclusion that must be reached if weight is given the opinions of many growers. This phase of orchard management is now receiving considerable attention at the Missouri Experiment Station. Quite an extensive experiment was begun in 1911. Many of the trees, however, were not set until a year or two later. From time to time, it has also been necessary to replant because certain trees died. The present planting, therefore, consists of trees of different ages.

rhe problem, primarily, has been to make observations relative to the effect of various kinds of intercrops and cover crops and methods of soil treatment upon the vigor, size, earliness of bearing, and amount of fruit produced upon apple trees set in the loess soil on the University Fruit Farm. The planting consisted of several commercial varieties but it was so arranged that several trees of each variety were included in each of the tillage plots.

In arranging the cropping systems, an attempt was made to provide various degrees of cultivation ranging from clean cultivation with a leguminous cover crop, to a permanent timothy and bluegrass sod. In one plot, the ground was kept in a high state of cultivation up until June each year when a crop of cowpeas or soybeans was planted. A second plot has grown successive crops of corn, a third has been planted to red clover in alternate years, a fourth has produced successive crops of alfalfa and another has been seeded to permanent timothy sod. Thus, it will be observed that two plots are cultivated each year, one is plowed in alternate years and the others (one planted with a legume and one with a grass) receive no cultivation. (As a matter of fact, it has been necessary to plow. and 
then reseed the alfalfa plot two or three times on account of bluegrass.)

This project has by no means been carried to its conclusion, for the older trees are just now beginning to come into bearing. However, the following data concerning the freezing point depression of twig and leaf sap are of interest in connection with the present problem and for that reason are presented here.

Table 41.-Effect of the Tillage Method Upon Depression of Twig Sap of APple Trees

\begin{tabular}{|c|c|c|c|c|c|c|c|}
\hline \multirow{2}{*}{\multicolumn{2}{|c|}{ Date }} & \multirow{2}{*}{ Varicty } & \multicolumn{5}{|c|}{ Depressions in the Various Plots } \\
\hline & & & Timothy & Alfalfa & Clover & Corn & Cowpeas \\
\hline \multirow{3}{*}{\multicolumn{2}{|c|}{ Mar. 11, 1916 ............ }} & Jonathan & 2.325 & 2.435 & 2.275 & 2.230 & 2.195 \\
\hline & & Benoni & 2.350 & 2.395 & 1.985 & 1.980 & 2.220 \\
\hline & & Delicious & 1.510 & 1.675 & 1.655 & 1.525 & 1.675 \\
\hline \multirow{3}{*}{\multicolumn{2}{|c|}{$\begin{array}{l}\text { Apr. } 10,1917 \\
\text { Nov. } 6,1917^{*}\end{array}$}} & Jonathan & 1.760 & 1.695 & 1.655 & 1.765 & 1.685 \\
\hline & & King David & 1.822 & 1.973 & 1.931 & 1.716 & 1.755 \\
\hline & & Ben Davis & 1.543 & 1.687 & 1.604 & 1.454 & 1.398 \\
\hline \multirow{2}{*}{\multicolumn{2}{|c|}{ Mar. 22, $1918^{*} \ldots$}} & King David & 1.439 & 1.517 & 1.482 & 1.339 & 1.215 \\
\hline & & Rome & 1.407 & 1.453 & 1.426 & 1.349 & 1.361 \\
\hline
\end{tabular}

*These determinations were made by A. J. Winkler.

Table 42.-Effect of the Tillage Method Upon the Depression of Leaf Sap of Apple Trees

\begin{tabular}{|c|c|c|c|c|c|c|c|c|}
\hline & \multirow{2}{*}{\multicolumn{2}{|c|}{ Date }} & \multirow{2}{*}{ Variety } & \multicolumn{5}{|c|}{ Depressions in the Various Plots } \\
\hline & & & & Timothy & Alfalfa & Clover & Corn & Cowpeas \\
\hline \multirow{3}{*}{ July } & & 1916 & Jonathan & 3.440 & ................. & 2.790 & 3.540 & 3.640 \\
\hline & & & Benoni & 3.160 & 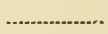 & 2.790 & 2.960 & 2.290 \\
\hline & & & Delicious & 3.400 & 2.830 & 3.460 & 3.500 & 2.490 \\
\hline \multirow[t]{4}{*}{ July } & 19, & 1916 & Jonathan & 2.725 & 3.070 & 2.553 & 2.290 & 2.195 \\
\hline & & & Delicious & 2.065 & 2.265 & 2.140 & 2.280 & 1.995 \\
\hline & & & Ben Davis & 2.770 & 2.305 & $2.030^{\circ}$ & 2.310 & 2.115 \\
\hline & & & King David & 2.470 & 2.755 & 2.925 & 2.530 & 2.405 \\
\hline \multirow{4}{*}{ Aug. } & 4, & 1916 & Jonathan & 2.285 & 2.520 & 2.200 & 2.465 & 2.570 \\
\hline & & & Delicious & 2.180 & 2.245 & 2.485 & 2.310 & 2.305 \\
\hline & & & Ben Davis & 2.260 & 2.505 & 2.385 & 2.220 & 2.180 \\
\hline & & & King David & 2.430 & 2.455 & 2.565 & 2.500 & 2.875 \\
\hline \multirow[t]{4}{*}{ Aug. } & 16 , & 1916 & Jonathan & 2.255 & 2.190 & 2.305 & 2.330 & 2.230 \\
\hline & & & Delicious & 1.935 & 2.040 & 2.125 & 1.975 & 1.875 \\
\hline & & & Ben Davis & 1.830 & 2.010 & 1.960 & 1.905 & 1.890 \\
\hline & & & King David & 2.210 & 2.440 & 2.615 & 2.500 & 2.140 \\
\hline
\end{tabular}

Table 41 shows very conclusively that the tillage method does materially affect the sap density of the twigs of apple trees. Contrary to what might have been expected, trees from the alfalfa plot show a greater depression of twig sap than trees from the timothy plot. As a general thing, there is not much difference between trees 


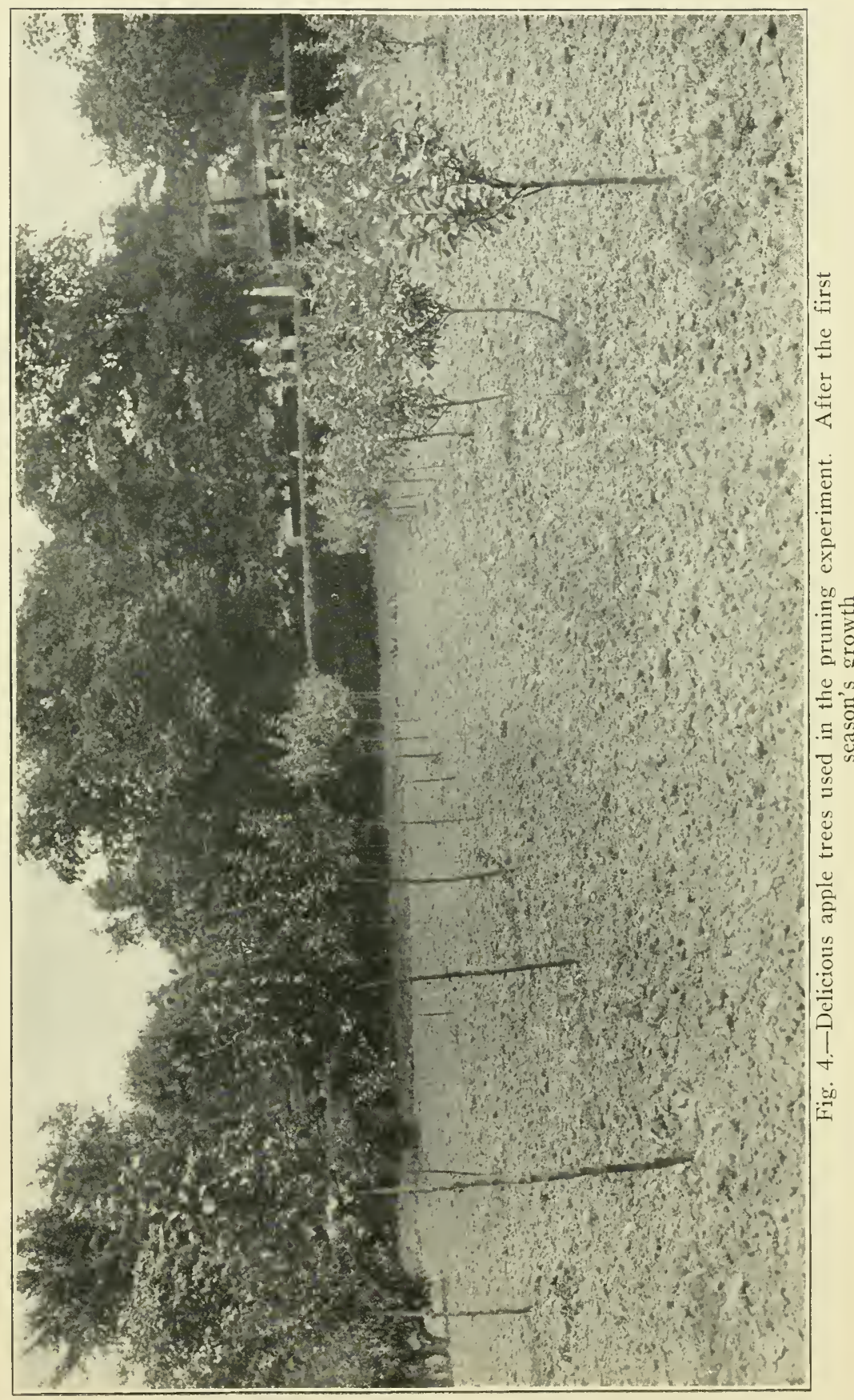




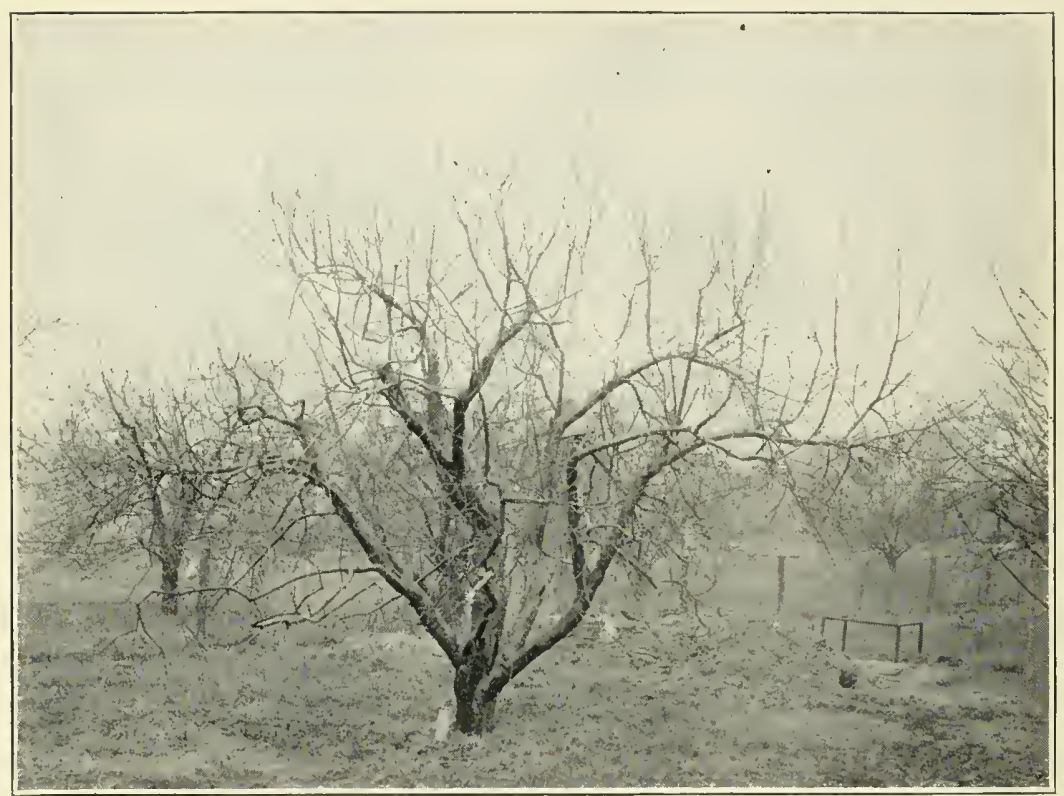

Fig. 5.-Jonathan apple tree showing effects of severe pruning. Note the large amount of watersprout growth. (Compare with Figure 6)

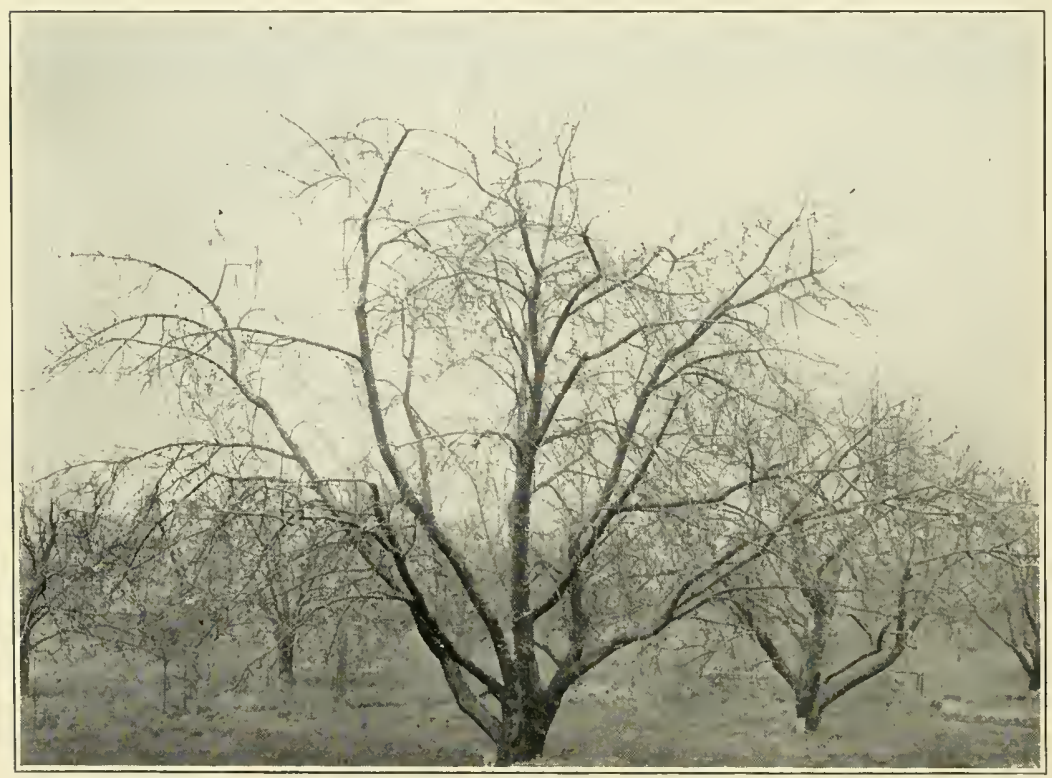

Fig 6.-Tonathan apple tree showing development of a large number of fruiting parts. (Compare with Figure 5, a tree of the same age but pruned more severely) 
growing in clover sod and those intercropped with corn. These stand next to timothy in density and first above the trees in the cowpea plot. In the latter case, the concentration is least of all.

From these data, it would seem logical to conclude that the trees growing in timothy or alfalfa should be the ones to come into bearing earliest, a conclusion also supported by general observations. However, it must be stated that the trees in the more intensively cultivated areas are considerably larger at the present time and hence, in this way may be able to overcome the advantage that the other trees may now possess.

The figures representing the depression of leaf sap from trees growing in the various plots present such a wide range of variation that no safe conclusion can be drawn.

\section{EFFECT OF THE PRLINING SYSTEM UPON THE FORMATION OF FRUITING PARTS}

That pruning does have is very marked influence upon the fruiting habit of the tree has long been a matter of common observation. Dormant pruning in most instances has tended to promote wood growth and to decrease fruitfulness. Even different amounts of pruning done at the same time show considerable variation in their effects.

That the system of pruning may likewise be influential in causing the formation of fruit spurs is also nicely shown by the following figures compiled from data collected under another project. A pruning experiment was begun in 1914 upon 64 one-year-old Delicious apple trees with the object of determining the relative influence of different pruning systems (particularly high heads vs. low heads) upon the size, the character of growth, and the fruiting age of apple trees. The experiment is incomplete, yet the following table is interesting in connection with the present problem.

The trees were very uniform in size and were treated in exactly the same manner except one series was forced to form the head at a height of about two feet and the other at five to six feet. The accompanying photograph (Fig. 4) indicates the appearance of the trees after their first season's growth.

From the beginning it has been very noticeable that the lowheaded trees make by far the greater amount of twig length growth and at the same time form a much larger number of branches. During the season of 1917, it was observed that the low-headed trees were forming a great many very short branches which made only a 
limited growth, usually two inches or less, and then formed a terminal bud. Since this is the usual history of the formation of fruiting parts, it has been assumed that these were potential fruit spurs. While a large number of such branches probably would never develop into fruit spurs under normal conditions, yet it is likely that the relative number in the two sets of trees would be maintained. A record of the number of these short branches as well as the number of longer twigs was taken in the fall of 1917. The figures are given in Table 43.

Table 43.-Average Number of Tivigs and Fruit Spurs on High- and LowHeaded Apple Trees

\begin{tabular}{|c|c|c|}
\hline & No. of Twigs & No. of Spurs \\
\hline High-headed ‥-н-1 & 35.5 & 14.9 \\
\hline Low-headed & 62.8 & 34.1 \\
\hline
\end{tabular}

From the foregoing it may be clearly seen that the system of pruning used has a very marked influence upon the number of potential fruiting parts formed in the early life of the tree, the low headed trees forming more than double the number of short branches or spurs found on the high-headed trees.

\section{EFFECT OF ETHERIZATION UPON THE SAP DENSITY OF APPLE TREE FRUIT SPURS AND LEAVES}

Etherization has proven to be a very effective stimulant upon the enzyme activity of detached parts of woody tissues. Howard ${ }^{\text {es }}$ has made extensive experiments along this line. Since this treatment does have a marked effect upon the availability of the food supply, the thought has come that perhaps etherization of the entire tree at various seasons of the year might have some effect upon the amount of available food and thus influence the number of fruit buds formed for the following season. For the above reason the following experiment has been designed and carried out.

The effect upon the food supply was measured by the concentration of the sap from the treated as compared with the untreated trees. While they plainly do not justify any definite conclusions, yet the results are submitted below.

A number of Jonathan apple trees were available for this work. They were five or six years old, just at the point where fruitfulness normally begins. They were growing in the clay loam soil of the Experiment Station grounds. 
Twelve trees were selected for etherization and a different one was etherized each month, beginning December, 1914, and continuing until November, 1915. For this exposure the trees were enclosed in a galvanized iron can and all joints tightly sealed. Ether was then introduced in sufficient quantity to have $0.5 \mathrm{cc}$. per liter of air space. A little injury to the leaves and new growth resulted from the May and June treatments. It was undoubtedly due to excessive temperatures inside the can at that time. Even tho an attempt was made to keep the temperature down by shading the can, yet it sometimes reached a fairly high point during the summer months. It is interesting to note that the trees treated in October began to show bud growth, especially near the ends of the main branches, early in November.

From time to time sap samples were secured from spurs and leaves on both etherized and unetherized trees. The results secured are given in Tables 44 and 45 .

Table 44.-Depression of Spur Sap from Etherized and Unethreized Trees

\begin{tabular}{l|c|c}
\hline \multirow{2}{*}{ Date } & \multicolumn{2}{|c}{ Depression } \\
\hline June 1,1915 & Treated & Untreated \\
\hline June 12,1915 & 1.630 & 1.580 \\
\hline
\end{tabular}

Table 45.-Depression of Leaf Sap from Etherized and Unetherized Trees

\begin{tabular}{|c|c|c|c|c|}
\hline \multirow{2}{*}{ Date of Etherization } & \multicolumn{4}{|c|}{ Depression on Date Given } \\
\hline & July 16,1915 & June 17,1916 & June 30,1916 & July 17,1916 \\
\hline December $12,1914 \ldots \ldots \ldots$ & 1.580 & 2.790 & 1.760 & 1.710 \\
\hline January 12, 1915 & 1.530 & 2.280 & 1.750 & 1.750 \\
\hline February 20, 1915 & 1.560 & 2.280 & 1.750 & 1.750 \\
\hline March 12, $1915 \ldots$ & 1.600 & 2.040 & 2.210 & 1.910 \\
\hline April $12, \quad 1915$ & 1.630 & 1.840 & 2.180 & 1.810 \\
\hline May 13, 1915 & 1.590 & 1.730 & 2.030 & 2.030 \\
\hline June $12, \quad 1916 \ldots$ & 1.610 & 2.200 & 1.680 & 1.640 \\
\hline July $13, \quad 1915 \ldots$ & 1.660 & 2.430 & 1.680 & 1.730 \\
\hline August 10,1915 & ....................... & 2.000 & 1.590 & 1.690 \\
\hline September 12, 1915 & (................... & 1.760 & 1.720 & 1.740 \\
\hline October $14, \quad 1915$ & & 1.970 & 1.760 & 2.060 \\
\hline November 15,1915 & n & 2.280 & 1.730 & 1.910 \\
\hline Check & 1.430 & 2.480 & 1.620 & 1.950 \\
\hline
\end{tabular}

The small supply of leaves and spurs on the trees prevented a large number of determinations and then, too, the work had to be discontinued after the first series. The results probably do not 
justify conclusions. It does seem, however, that ether has little effect upon the sap concentration of fruit spurs. The sap of the leaves apparently was affected by such treatment, but, as is seen by the later determinations, this effect does not carry over to the next year. The effect seems to be immediate. With the higher concentration of the leaf sap which comes in July because of etherization, the hypothesis might be advanced, that with a greater amount of food available a larger number of fruit buds might be formed. No supporting data, however, are furnished.

\section{SUMMARY AND CONCLUSIONS}

Missouri apple yields tend to rotate in three-year cycles, the sizes of the crops produced showing the following order: heavy, light, medium, heavy, etc.

A five-year study of the behavior of individual apple fruit spurs of six commercial varieties, as contrasted with previous opinions based upon casual observation of the entire tree or entire orchard, leads to the following conclusions:

Jonathan, Grimes and Winesap are able to develop a fairly high percentage of blooms each year, while Rome, York and Gano, produce an exceedingly high percentage of blooms one season and a very low one the next.

The varieties used show remarkable uniformity with respect to the percentage of the individual fruit spurs which alternate, that is, bloom only once in two years.

Jonathan and Winesap are able to develop blossoms in successive seasons on the same spur in a much greater proportion than the other varieties observed.

The soil in which a tree is growing has little effect, apparently, upon the performance of the individual spurs, with respect to alternation.

The fruitful year of certain alternating sorts may be changed by a removal of the blossoms thru either accident or design.

The age of the spur systems of the various varieties is practically the same, ranging usually from two to eight years, three to six or seven years being apparently the most effective fruiting age.

Sap from bearing spurs has a slightly higher concentration (lower freezing point) during a considerable portion of the year than sap from non-bearing spurs. The depression of the freezing point, however, gives no indication of the amount of starch which may be present. 
A marked decrease in the sap concentration of both bearing and non-bearing spurs occurs in late June or early July.

Leaf sap from bearing and non-bearing spurs shows considerable variation in concentration.

The number of fruits on a spur affects the concentration of neither spur nor leaf sap.

Sugar and starch are present in slightly greater amounts in the bearing spur than in the non-bearing one. (Determinations made by chemical methods.)

Bearing spurs have a smaller total leaf area than non-bearing spurs, the difference being due to the number of leaves developed rather than the size of the individual leaves.

Experiments in girdling nursery apple trees gave the following results :

Girdling, regardless of the season, caused an increased concentration of sap in the parts above the girdle and a decreased concentration in the parts below. (Determinations made by freezing-point method.)

Girdling produced its most marked effect in the parts nearest the girdle, the effect being lessened as the distance from the girdle increased.

Fertilizer experiments with dwarf Rome apple trees planted in boxes of sand or soil showed that effects upon (1) the size of the tree, (2) the development of its fruiting wood, and (3) the production of blossoms, could be attributed only to the use of nitrogen. Potash and phosphorus applied either singly or in combinations had no apparent effects.

Tillage experiments showed that trees growing in a permanent sod of either a grass or a legume had a higher concentration of twig sap than trees growing in plots planted with either annual or biennial cultivated crops.

Trees headed at five or six feet did not produce so many short branches-potential fruiting wood-during the first three years in the orchard, as trees headed at two feet.

Etherization of young Jonathan apple trees had little effect upon the concentration of either twig or leaf sap, and the small differences observed seemed to be only temporary. 


\section{BIBLIOGRAPHY}

1. Alderman, W. H. The Fertilization of Peach Orchards, W. Va. Agr. Exp. Sta. Bul. 150. 1915.

2. The Results of Apple Pruning Investigations, In Proc. Soc. Hort. Science, v. 12, p. 54-59. 1915.

3. - and Auchter, E. C. The Apple as Affected by Varying Degrees of Dormant and Season Pruning. W. Va., Agr. Exp. Sta. Bul. 158. 1916.

4. Pruning Fruit Trees, W. Va. Agr. Exp. Sta. Bul. 164. 1917.

5. Atkins, W. R. G. Some Recent Researches in Plant Physiology, Whittaker \& Co., New York and London. 1916.

6. Auchter, E. C. Five Years Investigations in Apple Thinning. W. Va. Agr. Exp. Sta. Bul. 162. 1917.

7. Bailey, L. H. Impressions of Our Fruit Growing Industries. Cornell Agr. Exp. Sta. Bul. 153. 1898.

8. - The Pruning Book, Macmillan Co., New York. 1911.

9. Ballard, W. S., and Volck, W. H. Winter Sprayings with Solutions of Nitrate of Soda. In Jour. Agr. Res. v. 1, p, 437-445. 1913.

10. Balmer, A. J., Pruning Orchard Trees. Wash. Agr. Exp. Sta. Bul. 25. 1896 .

11. Baranetzky, J. Fatty Reserves in Plant Tissues. In Bot. Centbl. v. 18 , p. 157.1884.

12. Barker, B. T. P., and Lees, A. H. Factors Governing Fruit Bud Formation (abstract). In Exp. Sta. Record. v. 37, p. 646. 1916.

13. Barry, P. The Fruit Garden. Saxton, New York. 1851. 1913.

14. Batchelor, L. D., Thinning Apples. Utah Agr. Exp. Sta. Cir, 12.

15. - and Goodspeed, W. E. The Summer Pruning of a Young Bearing Apple Orchard. Utah Agr. Exp. Sta. Bul. 140. 1915.

16. Beach, S. A. Thinning Apples. N. Y. (Geneva) Agr. Exp. Sta. Bul. 239. 1903.

17. Bouyoucos, G. J., and McCool, M. M. Determination of Cell Sap Concentration by the Freezing Point Method. In Jour. Am. Soc. Agron. v. 8, p. 50.1916.

18. Bradford, F. C. Fruit Bud Development of the Apple. Oregon Agr. Exp. Sta. Bu1. 129. 1915.

19. Briggs, L. J., Jensen, C. A., and McLane, J. W. The Mulched Basin System of Irrigated Citrus Culture and Its Bearing on the Control of Mottle-leaf, U. S. Dept. Agr. Bul. 499. 1917.

20. Brown, H. T., and Escombe, F. Influence of Varying Amounts of Carbon in the Air on the Photosynthetic Activity of Leaves and on the Mode of Growth in plants. In Proc. Roy. Soc. London, v. 70, p. 397-413. 1902.

21. - and Morris, G. H. A Contribution to the Chemistry and Physiology of Foliage Leaves. In Jour. Chem. Soc. v. 73, p. 604-676. 1893.

22. Butler, $\mathrm{O}$. On the Cause of Alternate Bearing in the Apple. In Torrey Bot. Club Bul. 44, p. 85-96. 1917.

23. Campbell, A. V. Carbohydrates of the Mangold Leaf. In Jour. Agr. Sc., v. 4, p. 248.1912. 
24. Chandler, W. H. Pruning Apple Trees with Some Notes on Their General Care. In Mo. State Board of Hort. Report, 5, p. 200-218. 1905.

25. The Killing of Plant Tissue by Low Temperature. Mo. Agr. Exp. Sta. Res. Bul. 8. 1913.

26. Chittenden, F. J. Floriferousness of 157 Varieties of Apples. In Jour. Roy. Hort. Soc. v. 39, p. 615-529. 1913-14.

27. Clark, V. A. Light as a Factor in Plant Culture. In Proc. Soc. Hort. Sc. v. 3, p. 24-32. 1905.

28. Cole, S. W. The American Fruit Book. Jewett, Boston, 1849.

29. Combes, R. Influence l'eclairment sur la formation des graines et sur leur pouvoir germinatif. In Rev. Gen. de Bot. v. 25, p. 130-141. 1913.

30. Copeland, E. B. The Relation of Nutrient Salts to Turgor. In Bot. Gaz. v. 24, p. 399-416. 1897.

31. Courtois, Jules. Lecture before Hort. Society of Seine-et-Oise. Reviewed by Butler (Bibl. No. 22).

32. Daniel, L. Effects de la decortication annulaire chez quelques plantes herbaces. In Compt. Rend. Acad. Sc. Paris. v. 131, p, 1253-55. 1900.

33. Davis, W. A., and Daish, A. J. The Estimation of Carbohydrates. In Jour. Agr. Sc. v. 5, p. 437. 1913.

34. — Methods of Estimating Carbohydrates. The Estimation of Starch. In Jour. Agr. Sc. v. 6, p. 152-168. 1914.

35. Dickens, Albert. Summer Pruning. Kan. Agr. Exp. Sta. Bul. 136. 1916.

36. Downing, A. J. Fruits and Fruit Trees of America. John Wiley, New York. 1864.

37. Drinkard, A. W., Jr. Fruit Bud Formation and Development. In Va. Exp. Sta. Report 1909-10, p. 159-205. 1909-10.

38. - Some Effects of Pruning. Root Pruning, Ringing and Stripping on the Formation of Fruit Buds on Dwarf Apple Trees. Va. Poly. Inst. Tech. Bul. 5. 1915.

39. Duke of Bedford and Pickering, S. U. Wooburn Exp. Fruit Farm Report 15 (Extract) Exp. Sta. Rec. v. 35, p. 37. 1916.

40. Favor, E. H. The Fruit Growers' Guide Book. The Fruit Grower, St. Joseph, Mo. 1911.

41. Field, Thos. W. Pear Culture. O. A. Moore, New York. 1859.

42. Fischer, A. Glycose als Reservestoff der Lauhhölzer. In Bot. Zeitschrift, p. 405.1888.

43. - Beiträge zur Physiologie der Holzgewachse. In Jahr. f wiss. Bot. v. 22, p. 73-160. 1891

44. Fischer, Henry. Ueber die Blutenbildung in ihrer Abhängigkeit vom Licht und ueber die blutenbildenden Substanzen. In Flora, v. 94, p. 478-490. 1905.

45. Fletcher, S. W. How to Make a Fruit Garden. Doubleday, Page \& Co., New York. 1910.

46. Forsyth, Wm. Culture and Management of Fruit Trees. Nichols \& Son, London. 1802.

47. Gardner, V. R. The Early Summer Pruning of Young Apple Trees. Ore. Agr. Exp. Sta. Bul. 130, p. 3. Pruning the Bearing Apple and Pear Tree, Ore. Agr. Exp. Sta. Bul. 130, p. 48-60. 1915. 
48. Gaucher, N. Practischer Obstbau. Paul Parey, Berlin. 1897.

49. Handbuch der Obstkultur. Paul Parey, Berlin. 1902.

50. Goethe, R. Die Obst- und Traubenzucht. Paul Parey, Berlin, 1900.

51. Goff, E. S. The Origin and Early Development of the Flowers in the Cherry, Plum, Apple and Pear. In Wis. Agr. Exp. Sta. Rpt. 16, p. 290303. 1899.

52. Investigation of Fruit-buds. In Wis. Agr. Exp. Sta. Rpt. 17, p. 266-285. 1900 .

53. - Investigations of Flower Buds. In Wis. Agr. Exp. Sta. Rpt. 18 , p. 304-316. 1901 .

54. Lessons in Fruit Growing. Univ. Coop. Assoc., Madison, Wis. 1902.

55. - The Principles of Plant Culture. 8th ed Macmillan Company, New York. 1916.

56. Gortner, R. A., and Harris, J. A. Notes on the Technique of the Determination of the Depression of the Freezing Point of Vegetable Saps. In Plant World, v. 2, p. 49.1914.

57. Gourley, J. H. The Effects of Fertilizer in a Cultivated Orchard. N. H. Agr. Exp. Sta. Bul. 168. 1914.

58. - Studies in Fruit-Bud Formation. N. H. Agr. Exp. Sta. Tech. Bu1. 9. 1915.

59. Green, S. B. Popular Fruit Growing. 5th ed. Webb. Pub. Co., St. Paul. 1917.

60. Gurney, C. W. Northwestern Pomology. Pub. by author. Concord, Neb. 1894.

61. Halsted, B. D. Reserve Food Materials in Buds and Surrounding Parts. Mem. Torrey Bot. Club, v. 2, p. 1-26. 1890.

62. Harris, J. A. and Gortner, R. A. Notes on the Calculation of the Osmotic Pressure of Expressed Vegetable Saps from the Depression of the Freezing Point. In Am. Jour. Bot. v. 1, p. 75-78. 1914.

63. An Extension to $5.999^{\circ} \mathrm{C}$. of Tables to Determine the Osmotic Pressure of Expressed Vegetable Saps from a Depression of the Freezing Point. In Am. Jour. Bot. v. 2, p. 418-419. 1915.

64. Hartwell, B. L. Starch Congestion Accompanying Certain Factors which Retard Plant Growth. R. I. Exp. Sta. Bul. 165. 1916.

65. Hedrick, U. P., Taylor, O. M., and Wellington, R. Ringing Herbaceouts Plants. N. Y. (Geneva) Agr. Exp. Sta. Bul. 288. 1907.

66. Heinicke, A. J. Factors Influencing the Abscission of Flowers and Partially Developed Fruits of the Apple (Pyrus malus. L.) Cornell Agr. Exp. Sta. Bul 393. 1917.

67. Herrick, R. S. Thinning the Winesap. Colo. Agr. Exp. Sta. Bu1. 170. 1910 .

68. Howard, W. L. Physiological Changes Accompanying Breaking of the Re t Period. Mo. Agr. Exp. Sta. Res. Bul. 21. 1915.

69. Howe, G. H. Ringing Fruit Trees. N. Y. (Geneva) Agr. Exp. Sta. Bul. 391. 1914.

70. Hibbard, R. P. and Harrington, O. E. Depression of the Freezing Point in Triturated Plant Tissues and the Magnitude of this Depression as Related to Soil Moisture. In Physiol. Researches, v. 1, p. 441-454. 1916. 
71. Ikeda, T. The Training and Pruning of Fruit Trees in Japan. In Jour. Roy. Hort. Soc. v. 36, p. 581-586. 1910.

72. Janse, J. M. Bark Ringing and the Descent of Sap. (Abstract). Exp. Sta. Rec. v. 32, p. 523. 1914.

73. Kains, M. G. Principles and Practice of Pruning. Orange Judd Co., New York. 1917.

74. Kayser, R. The Presence of Cane Sugar and Its Transformation Products in Plants. In Landw. Ver. Stat. v. 29, p. 461-73. 1883.

75. Kendall, E. C. A New Method for the Determination of Reducing Sugars. In Jour. Am. Chem. Soc. v. 34, p. 317-341. 1912.

76. Klebs, Georg. Numerous publications reviewed by M. G. Seliber. In Rev. Gen. de Bot. v. 18 (1906) p. 193-204, 252-257, 296-301, 332-343. 1889-1904.

77. _ - Alterations in the Development and Forms of Plants as a Result of Environment. In Proc. Roy. Soc. London, v. 82B, p. 547-558. 1910.

78. Knight, Thos. Andrew. Physiological and Horticultural Papers. Longman, Orme, Brown, Greene and Longmans, London. 1841.

79. Kraus, E. J. Pruning: The study of Fruit Buds. Ore. Agr. Exp. Sta. Bul. 130, p. 12-21. 1915.

80. Lake, E. R. The Apple in Oregon. Ore. Agr. Exp. Sta. Bul. 82. 1904.

81. Lewis, C. I. The Influence of Winter Pruning in Body Building and Spur Maintenance. In The Apple Annual: A Report of Fruit Growers' Conferences at National Apple Show. Spokane. 1915.

82. Lillie, R. S. The Physico-chemical Conditions of Anesthetic Action. In Science, n. s. v. 37, p. 959-972. 1913.

83. Lindley, John. The Theory of Horticulture. 2d Am. ed. John Wiley \& Sons, New York. 1881.

84. Livingston, B. E. On the Nature of the Stimulus Which Causes the Change of Form in Polymorphic Green Algae. In Bot. Gaz. v. 30, p. 289317. 1900.

85. Loew, Oskar. Zur Theorie der blutenbildenden Stoffe. In Flora. v. 94, p. $124-128.1905$.

86. Lovell, George. Some Observations on the Growth and Maturation of the Wood of Plants. In Trans. Hort. Soc. London. v. 4, p. 195-203. 1849.

87. Lubimenko, M. W. Influence de la lumiere sur le developpement des fruits et les graines chez les vegetaux superieurs. In Rev. Gen. de Bot. v. 22, p. 145-173. 1910.

88. Macoun, W. T. The Relation of Climate to Horticulture. In Proc. Soc. Hort. Sc. v. 9, p. 55-75. 1912.

89. Magness, J. R. The Influence of Summer-Pruning on Bud Development in the Apple. Ore. Agr. Exp. Sta. Bul. 139. 1916.

90 - The Underlying Principles in Summer Pruning. In The Apple Annual: A Report of Fruit Growers' Conferences at National Apple Show. Spokane. 1916.

91. - Pruning Investigations. Second Report Oregon Agr. Exp. Sta. Bul. 146. 1917.

92. Magnien, A. Fertilizer Experiments with Fruit Trees. (Abstract.) Exp. Sta. Rec. v. 29. p. 639.1913. 
93. Manaresi, A., and Tonegutti, M. The Chemical Composition of Wood from Different Branches of Fruit Trees. (Abstract.) Exp. Sta. Rec. v. 26, p. 407.1910.

94. Researches Concerning the Composition of the Wood and Bark of a Pear Tree. (Abstract.) Exp. Sta. Rec. v. 26, p. 407.1910.

95. Short Morphological and Chemical Studies of the Foliage from Different Branches of Fruit Trees. (Abstract.) Exp. Sta. Rec. v. 26, p. 407.1910.

96. May, J. E. Successful Experiments in Girdling Fruit Trees. In Mo. State Hort. Soc. Rpt. 47, p. 164-165. 1904.

97. Maynard, S. T. Girdling Apple Trees to Produce Fruitfulness. Mass. Hatch Exp. Sta. Bul. 1, p. 12-13. 1888.

98. —- Successful Fruit Culture. Orange Judd Co., New York. 1905.

99. Mobius, M. Historisches über den Ringelungsversuch. In Bot. Centbl. Beih. v. 21, p. 42-54.

100. Müller-Thurgau, H. Ablängigkeit der Ausbildung der Traubenbeeren und einiger anderer Früchte. In Landw. Jahrb. der Schweiz, v. 12, p. 135-205. 1898.

101. Nagai, I. On the Influence of Nutrition upon the Development of Sexual Organs in Fern Prothallia. In Jour. Col. Agr. Imp. Univ. Tokyo, v. 6, p. 121-164. 1915.

102. Newell, W. K. Apple Growing in the Pacific Northwest. Y. M. C. A. Portland. 1911.

103. Newsham, J. C. Progagation and Pruning. I:ckwood \& Son. London. 1913.

104. Noehden, G. H. On a Method of Improving the Productiveness of Fruit Trees. Trans. Hort. Soc. London. v. 2, p. 262-270. 1818.

105. Osterwalder, A. Ein Interessanter Fall von Blutenbildung bei unsern Obstbäumen. In Landw. Jahr. der Schweiz. v. 26, p. 293-294. 1912.

106. O'Sullivan, C. On the Estimation of Starch. In Jour. Chem. Soc. v. 45, p. $1-10.1884$.

107. Paddock, W. Experiments in Ringing Grape Vines. N. Y. (Geneva) Agr. Exp. Sta. Bul. 151. 1898.

108. - Pruning Fruit Trees. Colo. Agr. Exp. Sta. Bul. 106. 1905.

109. The Water Supply and Fruit Bud Formation. In Proc. Soc. Hort. Sc. v. 12, p. 51-54. 1915.

110. - and Whipple, O. B. Fruit Growing in Arid Regions. Macmillan Company, New York. 1911.

111. Pearson, A. H. Pruning Fruit Trees. In Jour. Roy. Hort. Soc. v. 19, p. 270-279. 1896.

112. Philips, Henry. The Companion for the Orchard. Colburn and Bentley, London. 1831.

113. Pickett, B. S. Fruit-bud Formation. N. H. Agr. Exp. Sta. Bul. 153. 1911.

114. Factors Influencing the Formation of Fruit Buds on Apple Trees. In Trans. Mass. Hort. Soc. Part I, p. 57-72. 1913.

115. Pickering, S. U. Fruiting of Trees in Consecutive Seasons. In Jour. Agr. Sc. v. 8, p. 131-138. 1916.

116. Pieters, A. J. The Relation Between Vegetative Vigor and Reproduction in Some Saprolegniaceae. In Amer. Jour. Bot. v, 2, p. 529-276. 1915. 
117. Price, W. A. Starch in Apple Trees. In Ohio. Jour. Sc. v. 16, p. 356-359. 1916.

118. Prince, W. R. Treatise on the Vine. New York. 1830.

119. Quinn, P. T. Pear Culture for Profit. Orange Judd Co., New York. 1892.

120. Remy, T. The Application of Nitrogen in Relation to Fruit-Bud Formation. (Abstract) Exp. Sta. Rec. v. 29, p. 539.1913.

121. Rivers, Thomas. The Miniature Fruit Garden. Orange Judd Co., New York. 1866.

122. Rosenberg, O. Die Stärke der Pflanzen in Winter. In Bot. Centbl. v. 66, p. $337-341.1896$.

123. Sablon, Leclerc du. Sur l'influence du sujet sur le greffon. In Compt. Rend. Acad. Soc. Paris, v. 136, p. 623-624. 1903.

124. - Sur les effects de decortication annulaire. In Compt. Rend. Acad. Sc., Paris, v. 140, p. 1553-1555. 1905.

125. - Recherches Physiologiques sur les materies de Reserves des Arbes. In Rev. gen. de. Bot. v. 18, p. 5-25. In Rev. gen. de Bot. v. 18, p. 82-96. 1906.

126. Schedlenberg, H. C. Ueber Hemicellulosen als Reserve-stoffe bei unsern Waldbäumen. In Ber. d. deut. Bot. Gesell. v. 23, p. 36-45. 1905.

127. Schweitzer, P. Ash Analysis of Twigs and Leaves from Apple Trees. In Mo. Agr. Exp. Sta. Ann. Rpt. 1898, p. 77-81. 1898.

128. Sears, F. C. Productive Orcharding. Lippincott, Philadelphia. 1914.

129. Shedd, O. M. Variations in Mineral Composition of Sap, Leaves and Stems of the Wild Grape Vine and Sugar Maple Tree. In Jour. Agr. Res. v. 5, p. 529-542. 1914.

130. Sorauer, P. A Treatise on the Physiology of Plants. Trans. by F. E. Weiss. Longsmans, Green \& Co., New York. 1895.

131. Stark, W. P. Inside Facts of Profitable Fruit Growing. Pub. by author. Neosho, Mo. 1916.

132. Stewart, J. P. Factors Influencing Yield, Size, Color and Growth in Apples. In Penna. State Col. Ann. Rpt. 1910-11, p. 401-510. 1910.

133 Cultural Methods in Apple Orchards. In Trans. Peninsula Hort. Soc. v. 6. 1917.

134. Sutherst, W. F. The Freezing Point of Vegetable Saps and Juices. In Chem. News, v. 84, p. 234. 1901.

135. Taft, L. R. Physiological Effects of Pruning. In Amer. Pom. Soc. Rpt. of 23d Session, p. 62-65. 1891.

136. Taylor, E. P., and Downing, G. J. Experiments in the Irrigation of Apple Orchards. Idaho Agr. Exp. Sta. Bul. 99. 1917.

137. Thomas, H. H., The Book of the Apple. John Lane, New York and London. 1902.

138. Thomas, J. J. The American Fruit Culturist. 21st ed. Orange Judd Co., New York. 1914.

139. Tull, Jethro. Horse Hoeing Industry. Corbett, London. 1822.

140. Van Deman, H. E. Girdling Fruit Trees. In Rural New Yorker, v. 73, p. 1181.1914.

141. Vincent, C. C. Winter versus Summer Pruning of Apple Trees. Idaho Agr. Exp. Sta. Bul. 98. 1917. 
142. Waldron, L. R. The Development of the Buds on the Wild Plum, Prunus Americana. N. D. Agr. Exp. Sta. Rpt. No. 10, p. 31-39. 1899.

143. Warder, John. American Pomology. Orange Judd Co., New York. 1867.

144. Waugh, F. A. The American Apple Orchard, Orange Judd Co., New York. 1910.

145. Whitten, J. C. Hints on Pruning Apple Trees. In Mo. State Bd. of Hort. Ann. Rpt. 4, p. 172-177. 1910.

146. Wickson, E. J. California Fruits. Pacific Rural Press, San Francisco. 1914.

147. Wilkinson, A. E. The Apple. Ginn \& Co., New York. 1915.

148. Winkler, C. H. Relation Between Vegetative and Reproductive Activity in Plants. Thesis, University of Mo. 1916.

149. Woods, C. D. Fertilizer Experiments on Apple Trees. Maine Agr. Exp. Sta. Bul. 236, p. 52-53. 1915.

150. W-, A. C. Annual Bearing of Apple Trees. In Rural New Yorker, Sept. 9, 1916.

151. Yeager, A. F. A Statistical Study of the Fruit Spur System of Certain Apple Trees. Ore. Agr. Exp. Sta. Bul. 139, p. 78-88. 1916.

152. Zacharias, E. Ueber Frucht and Samensatz von Kulturpflanzen. In Zeitschr f. Bot. v. 3, p. 785-795. 1911.

\section{BIOGRAPHY}

I, Cleo Claude Wiggans, was born on a farm near Princeton, Mercer County, Missouri, on October 20, 1889. I attended various country schools and then entered Princeton High School in 1904, graduating therefrom four years later. Entering the College of Agriculture in September, 1908, I was able to complete the requirements for the degree, Bachelor of Science in Agriculture, in three and one-half years. I held the position of Student Assistant in Horticulture in 1910-1911 and in 1911-1912. I entered the Graduate School of the University of Missouri in February, 1912. During the following school year I held a Research Fellowship in Horticulture at the same institution, and was granted the Master of Arts in June, 1913.

I was then appointed Assistant in Horticulture in the University of Missouri, which position I held for one year. I was then advanced in rank to Instructor in Horticulture, a position which I am holding at the present time. 



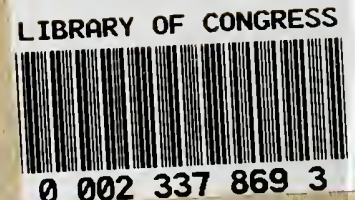

